\title{
Law, Sexual Morality, and Gender Equality in Qing and Communist China
}

\author{
Teemu Ruskola
}

The People's Republic of China (PRC) has plenty of laws on the books, yet one need be neither Chinese nor a Sinologist to be aware that those laws are frequently underenforced. 'This Note offers one explanation for the underenforcement by comparing Qing ${ }^{2}$ and PRC law. It first suggests that the two regimes are founded on a similar notion of the role of law, and then analyzes their laws governing sexual morality to illustrate that notion and to explain the failure of PRC authorities to enforce gender equality in their handling of certain sex offenses.

Part I of this Note starts with the familiar premise that traditional Chinese law, as it existed in the Qing, was essentially a moral code calling for social hierarchy and inequality. It then argues that the close identification of morality with law tended to make the latter aspirational and even unrealistic, so that Qing laws were sometimes little more than unenforced-or unenforceable-declarations of moral and ideological principles. Although the substantive law of the PRC bears little resemblance to that of the Qing, the underlying conception of law and its moral and social role is in many ways similar. A Confucian morality of inequality has given way to a socialist ethics of radical equality, yet modern Chinese legislation is no less moralistic by nature. This, in turn, tends to make PRC law equally aspirational and underenforced.

Part II illustrates the notion of law as an aspirational ideal of (in)equality by analyzing Qing and PRC laws governing certain sex offenses: marital

1. For instance, speaking of the freedoms of speech, the press, assembly, association, procession, and demonstration (proclaimed in various combinations under various PRC constitutions), Jerome Cohen calls it "[o]ne of the major unresolved puzzles of Chinese constitutionalism . . . why these freedoms continue to be asserted when to do so flies in the face of the everyday experience of the Chinese people." Jerome A. Cohen, China's Changing Constitution, 1978 CHINA Q. 794, 832. To be sure, Cass Sunstein, among others, has pointed out that many Communist constitutions merely "set out very general social aspirations or commitments" without creating "concrete entitlements that citizens can attempt to vindicate." Cass $R$. Sunstein, On Property and Constitutionalism, 14 CARDOZO L. REV. 907, 910 (1993). In the Chinese case, however, this aspirationalism is not limited to the Constitution, as this Note demonstrates.

2. The Qing regime lasted from A.D. 1644 to 1911 . Chinese names and words used in this Note are romanized following the pinyin system of the People's Republic of China. When sources cited use other systems, the pinyin transliteration is given in brackets. Chinese names of authors of English-language materials, however, are retained in the form used by authors themselves. 
transgressions (pre- and extramarital sexual relations), prostitution, and homosexual relations. It concludes that the governing moral principle in the Qing laws was gender inequality and in the PRC laws gender equality, and that, as moral principles rather than legal directives, the laws of both regimes have indeed been compromised.

In conclusion, this Note suggests that, ironically, it is the complete, or nearly complete, conflation of law with morality that makes law subject to abuse; as long as PRC laws calling for gender equality are viewed as laudable but not necessarily enforceable moral principles in the Qing tradition, they are liable to be compromised.

\section{LAW AS AN ASPIRATIONAL IDEAL}

Qing law and modern PRC law share a fundamental similarity: Both prefer rule by internalized morality to rule by law, which tends to make law a secondary form of social control and render it aspirational rather than coercive by nature.

\section{A. Qing Law: Aspiring to a Confucian Morality of Inequality}

Traditionally, Confucian ideologues preferred rule by internalized morality to the rule of law. Yet to the extent that law was a necessary tool of social control, it was harnessed to serve the traditional Confucian virtues whose essential purpose was "[to stabilize] a society that was ordered according to a hierarchy of age, and divided into kin-groups based on male dominance and male descent lines." ${ }^{3}$ The moral code became in effect the legal code. As a consequence of its moral nature, the law had to be relatively open-ended and flexible; two special devices, catch-all provisions and the analogy, evolved to ensure that any colorably immoral behavior was indeed punishable. Yet insofar as the law tended to call for the moral maximum, it often proved impracticable and hence at times was not enforced at all, or its enforcement was left to the discretion of extrajudicial institutions such as the family and the clan.

\section{Confucian Morality in the Law}

Traditional Chinese philosophy of law was predicated on the binary opposition between two radically different instruments of social control: $l i$, or moral suasion by rites, advocated by Confucian thinkers, and $f a$, or coercion by law, favored by the Legalist school of thought. ${ }^{4}$ In the "extravagantly

3. Mark Elvin, Female Virtue and the State in China, 104 PAST \& PRESENT 111, 111 (1984).

4. For a further analysis of the li-fa dichotomy, see, e.g., Benjamin Schwart, On Attitudes Toward Law in China, in Jerome A. Cohen, The Criminal Process IN tHe PEople's Republic of ChinA 1949-1963: AN INTRODUCTION 62 (1968). On the extensive connotations of $l i$, see HERBERT FINGARETTE, 
'idealistic' view" of the early Confucians, ${ }^{5}$ human nature is good, or at least capable of becoming good, ${ }^{6}$ so all that is needed is a government of superior men whose moral influence will transform those below through the functioning of $l i$. In the rather optimistic words of Confucius himself, "The rule of virtue can be compared to the Pole Star which commands the homage of the multitude of stars without leaving its place."7 Legalist thinkers, on the other hand, dismissed all appeals to virtue as naive and insisted that the average person operates on the crude pleasure-pain principle and can hence be controlled only by harsh penalties prescribed in unambiguous draconian laws. ${ }^{8}$

Upon eventually gaining political patronage, even Confucian ideologues found the "Pole Star" method of rule by $l i$ and the sheer force of superior virtue incapable of meeting all exigencies, and, as a concession to realpolitik, resorted to law as an instrument of social control. The penal sanctions of $f a$ were recruited to enforce the Confucian morality embodied in the $l i$. The moral code became, mutatis mutandis, the penal code; Ch'ï T'ung-tsu has characterized the process as the "Confucianization of law."

The notion that law was to enforce the morality of $l i$ resulted in complex and highly specific statutes. Since the $l i$ made fine distinctions based on sex, seniority, and degree of kinship, these distinctions were enshrined in the law as well. ${ }^{10}$ For example, instead of categorical provisions for intentional or

CONFUCIUS-THE SECULAR AS SACRED 1-17 (1972). For an analysis of moral freedom within the morality of $l i$, see Teemu Ruskola, Moral Choice in the Analects: A Way Without a Crossroads?, $19 \mathrm{~J}$. CHINESE PHIL. 285 (1992).

5. The characterization is Benjamin Schwartz's. See Benjamin Schwartz, Some Polarities in Confucian Thought, in CONfuCIANISM IN ACTION 50, 52 (David S. Nivison \& Arthur F. Wright eds., 1959).

6. On Confucian theories of human nature, see D.C. Lau, Theories of Human Nature in Mencius and Shyuntzyy [Xunzi], 15 BuLl. SCH. ORIENTAL \& AFR. STUD. 541 (1953).

7. CONFuCIUS, The ANALECTS 63 (D.C. Lau trans., 1979). In a similar vein, Confucius claimed, "Just desire the good yourself and the common people will be good. The virtue of the gentleman is like wind; the virtue of the small man is like grass. Let the wind blow over the grass and it is sure to bend." Id. at 115-16.

8. On Legalist thought in general, see, e.g., BENJAMIN I. SCHWARTZ, THE WORLD OF THOUGHT IN ANCIENT CHINA 321-49 (1985). For primary sources in translation, see HAN FEI TZU [HAN FEIZI], BASIC WrITNGS (W. Theodore de Bary ed. \& Burton Watson trans., 1964), and THE BOOK OF LORD SHANG (J.L. Duyvendak trans., 1928). For a comparison of Confucian and Legalist as well as Buddhist notions of law, see Luke T. Lee \& Whalen W. Lai, The Chinese Conceptions of Law: Confucian, Legalist, and Buddhist, 29 HASTINGS L.J. 1307 (1978).

9. Ch'Ü T'UNG-TSU, LAW AND SOCIETY IN TRADITIONAL ChINA 267-79 (1961). For more examples of the Confucianization of law, see DERK BODDE \& CLARENCE MORRIS, LAW IN IMPERIAL CHINA 30-38 (1967).

10. Sumptuary regulations in the Qing penal code, $\mathrm{Da}$ Qing $\mathrm{Lü} \mathrm{Li}$ [hereinafter Qing code], represent the most obvious example of the codification of Confucian status distinctions into the law. See THE GREAT QING CODE 180 (William C. Jones trans., 1994) [hereinafter JONES]; MANUEL DU CODE CHINOIS 389-92 (Guy Boulais trans., Taipei, Ch'eng-Wen Publishing Co. 1966) (1924) [hereinafter BouLAIS]. Citations to the Qing code in this Note refer to both Jones' English translation and Boulais's French translation. Jones' translation, more faithful to the original than Boulais's, contains only the statutes in the code, whereas Boulais's selection, though incomplete, includes both statutes and substatutes. Hence, this Note cites statutes to both Jones and Boulais, where possible, while substatutes are cited to Boulais only. (The Qing code consists of statutes, $l i i$, and substatutes, $l i$-distinct from "rites," supra Part I.A.1, also romanized as $l i$. The $l i i$, less than 500 in number, provided the basic legal principles and were modified, deleted, or added relatively infrequently, while the more detailed and more numerous $l i$ contained rules modifying or applying 
unintentional homicide, the Qing penal code had special statutes for the killing of a senior family member by a junior one, of a father by his child, of a master by his slave, and of a husband by his wife. ${ }^{11}$

These laws have frequently been characterized as embodying "the principle of inequality before the law."12 As a whole, the Qing judicial system undoubtedly upheld and promoted social inequality. Yet, analytically, this was not simply a matter of inequality before the law but, more fundamentally, of inequality in the law; it was not merely a question of biased application of the law (which undoubtedly also occurred), for the law itself, even when applied perfectly, treated members of different classes differently. ${ }^{13}$ As Confucian morality was one of hierarchy and inequality, so was Confucianized law.

\section{Expansive Qing Law: Catch-All Provisions and Analogy}

That moral duties became ipso facto legal duties called for laws with potentially infinite boundaries. As statute drafters could not envision all conceivably immoral acts, they needed special devices to expand the province of the law. The need was met by "catch-all" clauses and a provision for analogy. The former are exemplified by Qing statutes that penalized "vicious scoundrels"14 and flatly prohibited "[doing] that which ought not to be done."15 Analogy similarly filled in the moral lacunae in the law; where the law prescribed no punishment for socially objectionable conduct, the magistrate looked for guidance in the most closely analogous provision. ${ }^{16}$

the $l i ̈$ to special situations. See BODDE \& MORRIS, supra note 9, at 63-68; THOMAS A. METZGER, INTERNAL ORGANIZATION OF CH'ING [QING] BUREAUCRACY: LEGAL, NORMATIVE AND COMMUNICATION ASPECTS 84-87 (1973).) There is also an earlier English translation, TA TSING LEU LEE [DA QING LÜ LI]; BEING THE FUNDAMENTAL LAWS, AND A SELECTION FROM THE SUPPLEMENTARY STATUTES OF THE PENAL CODE OF CHINA (Sir George T. Staunton trans., London, Strahan and Preston 1810), which, however, is both inaccurate and incomplete. For a general discussion of the Qing code, see William C. Jones, Studying the Ch'ing [Qing] Code-The Ta Ch'ing Lü Li [Da Qing Lü Li], 22 AM. J. COMP. L. 330 (1974).

11. Marinus J. Meuer, The Introduction of Modern Criminal LaW IN China 4 (Taipei, Lung Men Bookstore 1967) (1949).

12. See, e.g., Clive Ansley, Chinese Criminal Law Under Manchus and Marxists, 20 U. BRIT. CoLUM. L. REv. 165, 184 (1986) (emphasis omitted).

13. To Anglo-American observers, justice generally means the application of one legal standard to all violators; everyone who kills should get the same penalty, other things being equal. In the Chinese criminal taxonomy, however, the other things are never equal and killing is hence not just one crime: a father killing his son, for example, is simply not the same act as a son killing his father. See, e.g., BODDE \& MORRIS, supra note 9, at 196-97. Therefore, the traditional Chinese system, taken on its own terms, is not an instance of one legal standard being applied differently to different people (i.e., inequality before the law) but of different people being governed by different standards (i.e., inequality in the law).

14. BoULAIS, supra note 10 , at 523 (providing for exile for "vicious scoundrels" who repeatedly cause trouble and molest decent people for no reason).

15. JONES, supra note 10 , at 359 ; BouLAIS, supra note 10 , at 704 . The statute was invoked relatively frequently; it is cited in 10 out of the 190 cases translated in Bodde's selection. BODDE \& MORRIS, supra note 9 , at 178 .

16. For instance, the Qing code penalized the common people for manufacturing silks embroidered with the imperial symbols of the dragon and the phoenix. JONES, supra note 10, at 408; BOULAIS, supra note 10, at 731. A literatus "who in preparing a biographical memoir of his deceased father, improperly made use of the word shê (amnesty)" was found guilty, by analogy, of manufacturing prohibited silks; the 
Both the catch-all provisions and analogy reflected a traditional Confucian prejudice against spelling out laws publicly; when people know the law, they will satisfy merely the letter of the law rather than remain in respectful fear of their superiors. ${ }^{17}$ The Roman principle of nulla poena sine lege-there shall be no punishment where there is no law-was wholly alien to the drafters of the Qing code. In their conception, assigning proper punishments was the primary function of the legal system while internalized morality provided the standard by which misconduct was recognized. Or, as Confucius himself expressed the preference for internalized morality over law, "Guide them by edicts, keep them in line with punishments, and the common people will stay out of trouble but will have no sense of shame. Guide them by virtue, keep them in line with rites, and they will, besides having a sense of shame, reform themselves." 18

\section{Qing Aspirations Compromised}

Besides the evolution of devides such as catch-alls and the analogy, another consequence of the pervasive Confucianization of law was that it eventually came to embody the moral ideal. While Anglo-American law is generally content to enforce the ethical minimum, traditional Chinese law often called for the moral maximum. ${ }^{19}$ The Chinese statute drafter was unlikely to ask what a "reasonable" daughter-in-law of the common law variety would do when struck by a tyrannical mother-in-law; instead, the relevant inquiry was

offender had improvidently suggested that his father, charged with administering a local granary, had granted an "amnesty" to peasants who could not meet their grain payments, although strictly speaking only the emperor had the power to grant an amnesty. That the writer indirectly likened his father to the emperor was deemed analogous to the lèse-majesté of producing imperial garments. BODDE \& MORRIS, supra note 9 , at 481-86. The statute requiring the use of analogy is not included in the selection by BouLAIS, supra note 10. For a translation, see JONES, supra note 10 , at 74. On the analogy generally, see Chen Chang Fumei, On Analogy in Ch'ing [Qing] Law, 30 HARV. J. AsIATIC STuD. 212 (1970) (suggesting that Qing magistrates invoked catch-all statutes more frequently than they employed the analogy to create new crimes).

17. When a minister of the state of Zheng in 536 B.C. engraved the penal code of his state on bronze tripods accessible to the public, he was censured strongly:

When the people know what the exact laws are, they do not stand in awe of their superiors.

They also come to have a contentious spirit, and make their appeal to the express words, hoping peradventure to be successful in their argument. ... When once the people know the grounds for contention, they will cast propriety away, and make their appeal to your descriptions [of the laws on tripods]. ... Disorderly litigations will multiply ....

Tso Chuen [Zuo ZhuAn], in 5 The Chinese Classics 609 (J. Legge ed. \& trans., reprint ed. 1960) (1876); see also Geoffrey MacCormack, Law and Punishment in the Earliest Chinese Thought, 20 IRISH JURIST n.s. 334, 345-47 (1985) (analyzing the critical contemporary reaction to publicizing laws).

18. Confucius, supra note 7 , at 63 .

19. Van der Sprenkel, for instance, has described Qing law as a "morally desirable standard." SYBILLE VAN DER SPRENKEL, LEGAL INSTTIUTIONS IN MANCHU CHINA: A SOCIOLOGICAL ANALYSIS 79 (1962). For contemporary advocacy of "morally maximal" legal standards, see Herbert Ma, The Legalization of Confucianism and Its Impact on Family Relationships, 65 WASH. U. L.Q. 667 (1987) (calling for greater "Confucianization" of R.O.C. Iaw in Taiwan and criticizing the general reduction of the law to an ethical minimum). 
what the ideal daughter-in-law would do in such a situation. No allowances whatsoever were made for the ideal son: parricide, the ultimate violation of filial piety, was deemed so heinous a crime that it was always punishable, whether intentional or not. ${ }^{20}$ Law took on a similarly unforgiving and puritanical tone in the area of sexual morality. ${ }^{21}$

By late Qing, much of the law had become so unrealistically demanding that it was virtually impossible to obey. Filial piety, for example, evolved into a duty that could simply not be fulfilled by the average person. Witness the case of a son whose sole failing was that he was too poor to support his parents in their old age: the parents were driven to suicide and the son was consequently sent into exile. ${ }^{22}$ The typical solution was a double standard that publicly condemned but privately accepted the gap between the moral ideal and social reality, or, as Confucius' favorite disciple put it, "The gentleman takes office in order to do his duty. As for putting the Way into practice, he knows all along that it is hopeless." ${ }^{23}$ The double standard seems to have been especially pronounced in the area of sexual morality. While official hagiography eulogized chaste widows, popular culture celebrated sensuality, ${ }^{24}$ and the general attitude to sex made a stark "private life/public face" distinction. ${ }^{25}$

The most unfair or unrealistically idealistic provisions were sometimes underenforced-or not enforced at all. This was usually the case with the law banning marriage between persons with the same last name, for example. ${ }^{26}$

20. W. Allyn Rickett, Voluntary Surrender and Confession in Chinese Law: The Problem of Continuity, 30 J. ASIAN STUD. 797, 802 (1971).

21. For instance, most of the "Ten Great Wrongs" (shi-e) (plotting rebellion, plotting high treason, plotting treason, gross unfilialness, killing three or more members of the same family, great disrespect to the throne, lack of filial piety, plotting murder or sale of relatives, disloyalty, and incest), JONES, supra note 10, at 34-36; BoulAIS, supra note 10, at 28-30, singled out by the Qing code are violations of sexual propriety or family ethics, or both. Similarly, many statutes with provisions for remission were not applicable in the case of sex offenses; for example, a provision allowing a reduction of penalties for those who made a voluntary confession did not apply to sexual transgressions. Id. at 70; see also Rickett, supra note 20, at 799; M.H. van der Valk, Voluntary Surrender in Chinese Law, 14 L.E. EuR. 359, 366-67 (1967). With an obsessive concern for adultery, the number of substatutes, see supra note 10 , governing a husband's responsibility for the homicide of an adulterous wife grew from 1 to 36 in the Qing, MARINUS

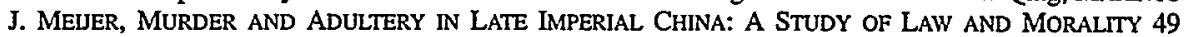
(1991), while the laws concerning ordinary murder underwent relatively few changes.

22. BODDE \& MORRIS, supra note 9, at 179; BOULAIS, supra note 10, at 648 (mandating exile for offspring whose indigence makes them unable to support their parents so that the parents commit suicide); see also Marinus J. Meijer, The Price of a P'ai-lou, 67 T'oung PAO 288, 302-04 (1981) [hereinafter Meijer, The Price of a P'ai-lou] (noting that if "an old father in a fit of anger because his son had served him tepid tea, grabbed a stick, ran after his fleeing offspring and died of a heart attack, or tripped over a stone, received 'internal injuries' and died, the son was held responsible and mostly banished").

23. Confucius, supra note 7, at 151. In Metzger's words, "[i]n virtually all periods Confucians perceived the society around them as corrupted and in tension with ideals almost beyond the possibility of implementation." METZGER supra note 10 , at 91 .

24. See Elvin, supra note 3, at 112-14.

25. The phrase is Sue Gronewold's. See SuE GRonEwold, BEAUTIFul MERCHANDISE: Prostituttion IN CHINA 1860-1936, at 22 (1985).

26. CH'Ü T'UNG-TSU, supra note 9, at 93 n.16. However, despite nonenforcement by the authorities, community pressure usually ensured observance of the taboo. 
Similarly, despite rigid rank differentiation in the law, when penalties were actually meted out to officials, the severity of most disciplinary sanctions depended only on the seriousness of the offense, not the privileged status of the offender. ${ }^{27}$

The enforcement of morality was in fact frequently left to the discretion of extralegal institutions more responsive to particular circumstances. Each clan $(z u)$, for instance, was governed by its own rules, which were often formally registered with the authorities and hence had a binding effect approaching that of law. ${ }^{28}$ Much as the Qing code, clan rules represented "Confucianism in application." ${ }^{29}$ Yet, significantly, clan rules were generally more lenient than the law, ${ }^{30}$ in effect, they constituted a tacit admission, as Wang Liu Hui-chen has put it, "that conduct in real life always tends to fall short of ideals."31

In short, traditional Confucian morality was encoded in the law, where it lent legitimacy to customary inequality. However, despite its rigid hierarchical character and in response to the unrealistic nature of its demands, Qing law accommodated occasional exceptions to the principle of inequality in the law.

\section{B. PRC Law: Aspiring to a Socialist Morality of Equality}

Upon its establishment, the PRC undertook to legislate a new socialist morality. While laws were revamped to call for a radical egalitarianism, the authorities' view of the role of law was informed by the traditional understanding; they preferred rule by internalized morality to a regime of laws, but insofar as laws were necessary, they were to enshrine socialist morality. As in the Qing, law had to remain open-ended in order to provide a broad enough umbrella to cover all possible violations of the official morality. To achieve this, the PRC has relied on the traditional devices: catch-all provisions and the analogy. Yet to the extent that PRC laws call for the moral maximum, they are liable to be compromised, much as Qing laws often were.

27. MEIZGER, supra note 10, at 398. Likewise, in Bodde's study of twenty cases of official misbehavior, only five officials actually received a reduced sentence, and many were in fact treated more harshly, apparently on a noblesse oblige theory: a superior man is morally obligated to provide a superior example. BODDE \& MORRIS, supra note 9, at 169-70.

28. Wang liu hui-Chen, The Tradmonal Chinese Clan Rules 23-24 (1959) [hereinafter The TRADITIONAL CHINESE ClaN RULES]. Clan rules provided sanctions for violations of customary morality that were likely to occur in an extended family. Generally, the types of prohibition and punishment ranged from simple prohibitions without punishments, oral admonition, ritual penalties, monetary fines, and corporal punishments, to expulsion from the clan genealogy, and even death or order to commit suicide, as well as punishment by authorities under the law. Id. at $36-46$.

29. Id. at 21 .

30. Id. at 23-24.

31. Id. at 23. 


\section{Socialist Morality in the Law}

The establishment of the People's Republic in 1949 ushered in a new morality of equality which found its expression in legislation as well. The Marriage Law of 1950 , for example, called for a radical equality of the sexes in marriage and family life. ${ }^{32}$ All methods of propaganda were used in disseminating it in order to establish a new equality among the people. ${ }^{33}$

32. Zhonghua Renmin Gongheguo Hunyinfa [Marriage Law of the People's Republic of China] (effective May 1, 1950) [hereinafter Marriage Law of 1950], arts. 1, 7, 9-12, 1949-50 Faling Huibian 35 (reprint ed. 1982), translated in MARINUS J. MEIJER, MARRIAGE LAW AND POLICY IN THE CHINESE PEOPLE'S REPUBLIC 300-01 app. (1971).

33. Marinus J. Meijer, Marriage Law and Policy in the People's Republic of China, in CHINESE FAMILY LAW AND SOCIAL ChANGE IN HistoriCAL AND COMPARATIVE PERSPECTIVE 436, $475-76$ (David C. Buxbaum ed., 1978) ("Perhaps there has never been written so much about any marriage law in the world as that of the People's Republic of China. Thousands of newspaper articles and millions of propaganda pamphlets have been devoted to it. Some three million cadres were mobilized to implement the law in 1953 ....."). In Meijer's observation, "[b]y far the greater part of the propaganda material was not directed at making the people aware of their rights, but at their political and moral education." Id. at 476. Julia Kristeva has similarly noted that, "compared to bourgeois legislation, the Marriage Law is rather a moral code than a law." JULIA KRISTEVA, ABOUT CHINESE WOMEN 130 (Anita Barrows trans., 1977).

Yet it is noteworthy that, despite the proclamations of equality in the Marriage Law and elsewhere, some classes still remain less equal than others, as in Qing China. Evoking Mao Zedong, the authoritative commentary on the Criminal Law states that the "primary task of China's Criminal Law is to resolve crimes in the nature of contradictions between the enemy and the people," while the resolution of "contradictions among the people" is only a secondary task. ZHONGGUO SHEHUI KEXUEYUAN, FAXUE YANIUSUO, XINGFA YANJIUSHI [CRIMINAL RESEARCH GROUP, LAW INSTITUTE, CHINESE ACADEMY OF SOCIAL SCIENCES], ZHONGHUA RENMIN GONGHEGUO XINGFA JIANGHUA [LECTURES ON THE CRIMINAL LAW OF THE PEOPLE'S REPUBLIC OF CHINA] (1979), translated in CHINESE L. \& Gov'T, Summer 1980, at 17-18 [hereinafter LECTURES ON THE CRIMINAL LAW]. (On Mao's fundamental distinction between the two kinds of contradictions, see MAO TSE-TUNG [MAO ZEDONG], ON THE CORRECT HANDLING OF CONTRADICTIONS AMONG THE PEOPLE 2-17 (1966).)

The provision of harsher penalties to the enemies of the people has been defended by appeal to a distinction between "juridical" and "legislative" equality:

When we declare that all citizens are equal before the law, it is from the juridical point of view, that is, the law applies equally to all citizens. Legislatively, there is no stipulation that all citizens are equal; instead, the people must be distinguished from the class enemy. . . . These provisions in the Constitution reflect the class nature of the law.

Active Judicial Circles, 22 BEIJING REV., Jan. 12, 1979, at 35. In essence, this is but a rationalization of the traditional legal double standard in the Qing: while everyone may be entitled to equality before the law, or juridical equality, enemies of the people are not entitled to equality in the law, or legislative equality, but may in fact be singled out for harsher treatment. See supra notes 12-13 and accompanying text.

Counterrevolutionaries as a group are indeed treated much as the traditional déclassés in the Qing code. For instance, the harboring of counterrevolutionary criminals and the harboring of ordinary criminals are treated as two different crimes in the Criminal Law, and a harsher penalty attaches to the former offense. Zhonghua Renmin Gongheguo Xingfa [Criminal Law of the People's Republic of China] [hereinafter Criminal Law], art. 162, 1979 Fagui Huibian 81, reprinted and translated in THE CRIMINAL

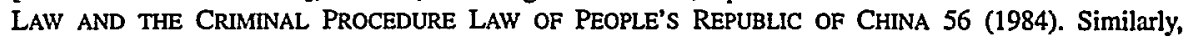
counterrevolutionary homicide, Criminal Law, supra, art. 101, is distinct from ordinary homicide, id. arts. 132,133 , just as in the Qing killing a stranger, for instance, was a less serious crime than killing a relative. Furthermore, counterrevolutionaries-and recidivists, who by definition show little capacity for reform-are not eligible for suspensions of sentence, $i d$. art. 69; committing a counterrevolutionary crime constitutes the ultimate violation of political morality and is hence unpardonable, much like the "Ten Great Wrongs" in the Qing code, see supra note 21. Since law has internalized political morality, it is indeed possible to analyze counterrevolutionary crime as a legal concept, just as it was possible in the Qing to analyze filial piety as a legal concept because the law had internalized the dictates of Confucian morality. 
Yet, despite the novelty of the notion of equality, Communist law is founded largely on the same moral theory as Confucian law: a faith in the human capacity to reform. As Mencius, the perennially optimistic early Confucian, declared that through self-cultivation any man could become a Yao or Shun, the moral paragons of old, ${ }^{34}$ so also the PRC proclaims it the goal of its Criminal Law "[to make] every effort to change [the criminal] into a new man. ${ }^{35}$ Indeed, the cult of Lei Feng, the former revolutionary saint, has recently been revived to inspire the masses to cultivate their Communist virtue ${ }^{36}$ not unlike the Confucian sages routinely invoked by the imperial government.

As a corollary of the faith in human perfectibility, Communism as an ideology also shares the Confucian preference for rule by internalized morality rather than law. In the true Communist utopia to come, as in the lost society of the Confucian Golden Age, everyone will realize that his or her individual interest lies in advancing the collective interest; private conflicts only arise in capitalist societies driven by the profit motive. ${ }^{37}$ Rather like the Confucian believers in $l i$, the authoritative commentators on the Criminal Law of the PRC maintain that "although China's Criminal Law is an important method used in the work of administering the country and struggling against crime, it is neither the sole nor the primary method."38 In the end, the goal is to render law superfluous by making people "spontaneously observe the Constitution and the law, spontaneously maintain the social order, the order of production, [and] the order of work."39 The sentiment is echoed even in the Criminal Procedure Law, which proclaims it one of its goals "to educate citizens to observe the law voluntarily." ${ }^{40}$ In the Sinified version of socialism, Marxist self-cultivation has thus replaced Confucian self-cultivation as the moral and political ideal, ${ }^{41}$ Liu Shaoqi's How To Be a Good Communist ${ }^{42}$ has

34. MENCIUS, MENCIUS 172 (D.C. Lau trans., 1970).

35. LECTURES ON THE CRIMINAL LAW, supra note 33, at 31.

36. See, e.g., Qiushi Commentator: In Emulating Lei Feng, It Is Important To Grasp the Essence, Xinhua, Mar. 4, 1991, translated in FOREIGN BROADCAST INFORMATION SERVICE-DAILY REPORT: CHINA, Mar. 6, 1991, at 13.

37. As David Nivison has noted, there is a fundamental identity in the Communist and Confucian conceptions of virtue. The Communist Party calls for "the utter subordination of individual interest to that of the party and, ultimately, that of mankind"; similarly, in Nivison's words, "[i]f we substitute "prince" for 'party,' Confucian 'loyalty' could scarcely be better formulated." David S. Nivison, Communist Ethics and Chinese Tradition, 16 J. ASIAN STUD, 51, 60 (1956).

38. LeCTURES ON THE CRIMINAL LAW, supra note 33, at 16.

39. Id. at 20 .

40. Zhonghua Renmin Gongheguo Susongfa [Criminal Procedure Law of the People's Republic of China] [hereinafter Criminal Procedure Law], art. 2, 1980 Fagui Huibian 89, reprinted and translated in The Criminal LaW and the Criminal Procedure LaW of tHe People's Republic of China, supta note 33 , at 115 .

41. On Confucian and Communist self-cultivation, see generally Nivison, supra note 37.

42. LIU SHAO-CHI [LIU SHaOQI], How TO BE a GOOD COMMUNIST (1951) (translated from the Chinese LUN GoNGCHAN DaNGyuaN DE XIUYANG (1949)). 
superseded the Confucian Analects ${ }^{43}$ as the guidance manual in practical morality.

The moralistic nature of PRC law is reflected in its punishments as well; they include requiring an offender to sign a statement of repentance, ${ }^{44}$ reprimanding him, and ordering him to apologize. ${ }^{45}$ The 1980 Lawyers' Regulations also recognize the relevance of socialist morality to law by calling for lawyers to "warmly love" China and its socialist system. ${ }^{46}$

\section{Expansive PRC Law: Catch-All Provisions and Analogy}

PRC laws are generally drafted in sweeping terms and plain, nontechnical language. The lack of specificity results partly from the use of law as an educational tool: the law must be easy to comprehend. Yet the drafting style frequently results - hardly coincidentally -in catch-all provisions under which the authorities can enforce state morality. Substantively, PRC laws proscribing acts of "hooliganism" (liumangzui), ${ }^{47}$ for instance, appear no different from the "vicious scoundrel" statutes in the Qing." Similarly, the prohibition of "[a]1l acts endangering the People's Republic of China committed with the goal of overthrowing ... the socialist system" "[doing] that which ought not to be done" ${ }^{\mathrm{S0}}$ in the Qing.

Analogy is another device familiar from the Qing arsenal of legal technology ${ }^{51}$ Like the catch-all provisions, it is a natural consequence of the

43. See supra note 7.

44. Zhonghua Renmin Gongheguo Zhi'an Guanli Chufa Tiaoli [Regulations of the People's Republic of China on Security Administration Punishment] [hereinafter Security Administration Punishment Act or SAPA], art. 30, 1986 Fagui Huibian 160-61 (specifying sanctions in prostitution cases that do not merit official prosecution).

45. Criminal Law, supra note 33, art. 32 (specifying sanctions for offenders where crime is minor).

46. Zhonghua Renmin Gongheguo Lüshi Zhanxing Tiaoli [Interim Regulations of the People's Republic of China on Lawyers], 1980 Fagui Huibian 44 (1986), translated in 19 I.L.M. 1456 (1980), cited in Timothy A. Gelatt, Lawyers in China: The Past Decade and Beyond, 23 N.Y.U. J. INT'L L. \& POL. 751, 756 (1991).

47. E.g., Criminal Law, supra note 33, art. 160. For a discussion of the problems posed by the vague language and loose definitions employed in PRC laws as well as the often inconsistent and imprecise use of legal terminology, exemplified here by the term "hooliganism," see generally David Finkelstein, The Language of Communist China's Criminal Law, 27 J. ASIAN STUD. 503 (1968).

48. See supra note 14.

49. Criminal Law, supra note 33, art. 90 . On the sweeping nature of the definition of counterrevolutionary crime, see, e.g., Marinus J. Meijer, The New Criminal Law of the People's Republic of China, 6 REV. SOCIALIST L. 125, 132 (1980).

50. See supra note 15 .

51. However, while the Qing code mandated the use of analogy, see supra note 16 , the Criminal Law of the PRC merely permits it. Criminal Law, supra note 33, art. 79. Analogy has been justified as an interim measure "to meet practical needs and plug the loopholes" until the PRC legal system fully matures. Leng Shao-chuan, Criminal Justice in Post-Mao China: Sonte Preliminary Observations, 73 J. CRIM. L. \& CRIMINOLOGY 204, 213 n.56 (1982). Regardless of the official justification, analogy effectively gives the authorities carte blanche to enforce their own conception of socialist morality. Analogy is in fact one of the most criticized features of substantive law in the PRC, since it makes possible the creation of ex post facto laws, as defined in the International Covenant on Civil and Political Rights. International Covenant on Civil and Political Rights, Dec. 19, 1966, art. 15, 999 U.N.T.S. 171; LAWYERS COMMITTEE FOR HUMAN 
moralistic nature of PRC law: Both are convenient devices for protecting against gaps in the law, and both reflect the traditional premise that the law provides the penalties while internalized morality provides the unarticulated but generally known standards by which misconduct is recognized. Although the PRC appears to have used the analogy relatively infrequently, ${ }^{52}$ even the threat of its application constitutes a reminder that merely observing the letter of the law may not be enough; much as in the Qing, it may be more effective not to spell out the laws but to keep people on guard.

\section{PRC Aspirations Compromised}

To the extent that the PRC equates law with morality as the Qing did, it, too, frequently finds itself faced with aspirational laws whose highly desirable standards are simply unrealistic. Despite unequivocal prohibitions against infanticide, for example, officials often choose not to prosecute cases, usually of female infanticide..$^{53}$ Even when they do, usually only the Marriage Law of 1980 is cited ${ }^{54}$ as opposed to the stricter provisions in the Criminal Law against homicide, which similarly indicates a willingness to compromise the flat prohibition..$^{55}$ To the extent that economic need in many rural areas makes male children a necessity, ${ }^{56}$ authorities often simply ignore the law. Indeed, economic reform often takes precedence over egalitarian aspirations. The

Rights, Criminal Justice with Chinese Characteristics: China's Criminal Process and VIOLATIONS OF HUMAN RIGHTS 81 (1993).

52. According to one scholar, there were only 51 reported cases where analogy was applied in the period between 1980 and 1991. LAWYERS COMMITTEE FOR HUMAN RIGHTS, supra note 51, at 82. The future of the analogy is in fact uncertain. The new SAPA, supra note 44, replacing the 1957 SAPA Zhonghua Renmin Gongheguo Zhi'an Guanli Chufa Tiaoli [Regulations of the People's Republic of China on Security Administration Punishment], 1957 Fagui Huibian 245 (reprint ed. 1982), translated in CoHEN, supra note 4, at 205-37, for example, eliminated the analogy completely. Retention of the analogy in the Criminal Law is under debate as well, as it has been since its promulgation. See, e.g., LAWYERS COMMTTTE FOR HUMAN RIGHTS, supra note 51, at 81-82; Zhou Mi, Zuixing Fading Haishi Fali Leitui? [Should Crimes Be Stipulated or Analogized?], FAXUE YANIIU [STUdies IN LAW], No. 5, 1980, at 25.

53. Female infanticide continues to be a serious problem, especially in rural areas. While the internationally accepted normal ratio of male to female births is 106:100, in Guangdong the male to female ratio of births reported in the 1982 census stands at 110.5:100 and in Anhui at 112.5:100. Julie Jimmerson, Female Infanticide in China: An Examination of Cultural and Legal Norms, 8 PAC. BASIN L.J. 47, 65-66 (1990). On female infanticide in general, see, e.g., MARY ANNE WARREN, GENDERCIDE: THE IMPLICATIONS OF SEX SELECTION 34-41 (1985).

54. Zhonghua Renmin Gongheguo Hunyinfa [Marriage Law of the People Republic of China] (effective Jan. 1, 1980) [hereinafter Marriage Law of 1980], art. 15, 1980 Fagui Huibian 8, translated in BEIING REV., Mar. 16, 1981, at 24. While the article does prohibit infanticide, it prescribes no punishment. The Marriage Law does, however, provide that violators shall be subject to administrative punishments "according to law and the circumstances." Marriage Law of 1980, supra, art. 34.

55. See Jimmerson, supra note 53, at 67 n.106.

56. Despite proclamations of the equality of virilocal (wife moves in with her husband's family) and uxorilocal (husband moves in with his wife's family) marriages, Marriage Law of 1980, supra note 54, art. 8, daughters still usually marry out virilocally. Couples without male children are therefore left with no source of support in their old age. Jimmerson, supra note 53, at 47-48. 
constitutional guarantee of equal pay for equal work ${ }^{57}$ is often fulfilled in form only: while both men and women may receive the same pay for each "workpoint," women are awarded fewer workpoints than men for performing the same tasks. ${ }^{58}$

In short, although in general PRC laws are largely the reverse image of Qing laws, substituting the principle of equality ${ }^{59}$ for that of inequality, the role of law itself seems to have changed little. The authorities still prefer rule by internalized morality to a rule of law, and, to the extent that laws are necessary, they tend to reflect the moral ideal, whether practicable or not.

\section{Chinese Laws Governing Sexual MoraltTy: A Call for Gender (IN)EQUALITY}

A comparative analysis of Qing and PRC laws governing certain areas of sexual morality further illustrates the traditional notion of law as an aspirational call for (in)equality. It can explain, at least in part, the striking underenforcement of the laws calling for equality of the genders in the area of sexual morality in China today.

\section{A. Sex Offenses in the Qing: A Call for Gender Inequality}

In keeping with traditional morality, the underlying principle of Qing laws governing marital transgressions (pre- and extramarital sexual relations), prostitution, and homosexual relations was that of gender inequality.

57. XIANFA (1982) [Constitution], art. 48, translated in THE CONSTITUTION OF THE PEOPLE'S REPUBLIC OF CHINA 38 (Foreign Languages Press trans., 1983).

58. MARGERY WOLF, REvolution POSTPONED: WOMEv IN CONTEMPORARY CHINA 100-03 (1985). Likewise, the economic revolution has trumped the sexual revolution by giving companies greater latitude in hiring and firing, thereby effectively allowing women to be hired last and fired first. Michael Palmer, China, People's Republic of: Reacting to Rapid Social Change, 28 J. FAM. L. 438, $452-54$ (1989-90); Sheryl WuDunn, Layoffs in China: A Dirty Word, but All Too Real, N.Y. TIMES, May 11, 1993, at A4. Similarly, while the new Inheritance Law provides for equality of the sexes in intestate succession, sex discrimination is allowed in testate succession in the interest of providing for free and efficient capital accumulation, which indeed represents, in Louis Schwartz's phrase, "a clear preference for freedom of alienation over the state policy of preventing sexual discrimination." Zhonghua Renmin Gongheguo Jichengfa [Inheritance Law of the People's Republic of China], in ZHONGHUA RENMN GONGHEGUO FALU QUANSHU [COMPLETE LAWS OF THE PEOPLE'S REPUBLIC OF CHINA] 326 (1989), translated in Louis B. Schwartz, The Inheritance Law of the People's Republic of China, 28 HARV. INT'L L.J. 433, 454, 457 app. (1987).

59. Yet, however laudable these principles may be, even the laws as written sometimes betray lapses in the drafters' understanding of how to uphold equality. For instance, in cases of abuse by family members, both the Criminal Law and the Security Administration Act provide for enforcement only upon the complaint of the abused, Criminal Law, supra note 33, art. 182; SAPA, supra note 44, art. 22, just as the Qing spousal abuse statute did. See infra note 68. Since the abused is much more likely to be female, the provision effectively discriminates against women. (The Criminal Law does note, in defining the phrase "to be handled only upon complaint," that where coercion or intimidation prevents the victim from bringing a complaint, the procuratorate or a close relative may bring the complaint on his or her behalf. Criminal Law, supra note 33 , art. 87.) 


\section{Marital Transgressions}

Marriage and family stood at the very center of Qing society and culture. Ultimately, the most important purpose of marriage was ancestor worship; without a descendant to continue the line, one's ancestors would have no one to sacrifice to them and they would become unworshipped ghosts. ${ }^{60}$ Failure to procreate was thus an unfilial act of grave consequences. Hence, the family occupied a central place in the collective consciousness. Of the "Five Relationships" on which the Confucian social vision rested, three were familial, ${ }^{61}$ and even politics was frequently conceptualized in terms of familial metaphors, with the emperor as a pater familias writ large. ${ }^{62}$

While the general importance of family to the welfare of the polity was universally acknowledged ${ }^{63}$ its autonomy was equally well respected. As Benjamin Schwartz has put it, although laws regulating marriage do appear in the books, "the general assumption is that respectable people will be able to settle such matters outside of court." ${ }^{64}$ Marriage in the Qing was essentially a customary, not legal, institution; no registration with the bureaucracy was required. ${ }^{65}$

Hence, even where laws regulating marriage or family did exist, their enforcement was frequently left to the family, clan, or other extrajudicial institutions. In many ways the family represented, in effect, the lowest level

60. CH'U T'UNG-TSU, supra note 9, at 91 .

61. The "Five Relationships" are those between sovereign and subject, father and son, husband and wife, elder and younger son, and the relationship between friends. See THE DOCTRINE OF THE MEAN, in 1 The ChINESE Classics, supra note 17, at 406-07.

62. Analogously, district magistrates were popularly known as fumuguan, or "father and mother officials." CH'U 'T'UNG-TSU, LOCAL GOVERNMENT IN CHINA UNDER THE CH'ING [QING] 14 (1962).

63. Indeed, in the early Confucian vision, there was no question that, should duties to the family and the state conflict, the family would always take precedence over the state. Confucius unequivocally denounced a son who reported that his father had stolen sheep: "Fathers cover up for their sons, and sons cover up for their fathers. Straightness is to be found in such behaviour." CoNfuClus, supra note 7, at 121. The Qing code in fact made it a punishable offense for a son to report his father's criminal acts. It prescribed the penalty of three years' imprisonment and one hundred strokes when the report turned out to be correct, and strangulation when it turned out to be untrue. JONES, supra note 10, at 322; BouLAIS, supra note 10, at 644-45. However, in order to qualify as state ideology, even Confucianism ultimately had to recognize the supremacy of state over family: while the law recognized the right, and, indeed, duty, to conceal certain family members who had violated the law, these laws were not valid in cases of high treason where the state's authority was seriously threatened. JONES, supra note 10, at 323; BoULAIS, supra note 10, at 645; see also CH'U T'UNG-TSU, supra note 9, at 70-74. (This parallelled a provision that exemptions from punishment for lunatics were inapplicable in cases of rebellion. See Karl Bünger, The Punishment of Lunatics and Negligents According to Classical Chinese Law, 9 STUDIA SERICA 1, 4-5 (1950).)

64. Schwartz, supra note 4 , at 68 .

65. Vermiter Y. ChIU, MARRIAGe LaW AND Customs of ChINA 75 (1966). Note that divorce was an equally private affair which required no registration. Linda Wong, Family Reform Through Divorce Law in the PRC, 1 PAC. BASIN L.J. 265, 279 (1982). Even when the law did regulate conduct within the family, it was frequently enforced on complaint only; magistrates tended to make a pragmatic distinction between civil and criminal suits-although the law itself did not-and investigate the former only on complaint. BODDE \& MORRIS, supra note 9, at 118-19. 
of law enforcement. ${ }^{66}$ For instance, the clan rules of one typical clan made it a punishable offense for a father to let his son visit prostitutes, for juniors to act unfilially, and for a widow with a son to remarry. ${ }^{67}$ The clan rules also allowed for systematic discrimination against the female members of the family, thus reflecting the gender inequality of the official statutory morality. ${ }^{68}$ The original Confucian indifference to women ${ }^{69}$ eventually evolved into an attitude that has been characterized as misogynist, ${ }^{70}$ exemplified by such maxims as "Starving to death is a small matter, but losing one's chastity is a grave matter"" and "Lack of talent is a virtue in a woman."72

"Marriage" was defined broadly, for it included concubinage and relations with one's slaves. ${ }^{73}$ Indeed, until 1673 , the law made no distinction between single and married female slaves-both could be used for sex. ${ }^{74}$ Yet this "extended family" was very much a man's family: unlike the master, both the wife and daughters were decapitated for sex with male slaves. ${ }^{75}$ Similarly,

66. CH'Ü T'UNG-TSU, supra note 9, at 40. On clan organization in general, see VAN DER SPRENKEL, supra note 19, at 80-89. For a detailed analysis of clan rules, see THE TRADITIONAL CHINESE CLAN RULES, supra note 28.

67. VAN DER SPRENKEL, supra note 19 , at 82-83.

68. For instance, the statutory penalty for a wife who beat her husband was a hundred strokes, even if he was not injured, JONES, supra note 10, at 299; BOULAIS, supra note 10, at 608; see also CH'U T'UNGTSU, supra note 9, at 106, and if he was injured seriously, the law in fact required that he divorce her; a wife's injuring her husband amounted to "breaking the bond," see infra note 86 , which called for a mandatory divorce. See CH'Ü T'UNG-TSU, supra note 9, at 107. In contrast, if a man injured his wife seriously, divorce was possible only if he consented to it. JoNES, supra note 10, at 299-300; BoULAIS, supra note 10, at 609; see also CH'Ü T'UNG-TSU, supra note 9, at 107. A husband was punished for wife-beating only if her injuries were serious and she lodged a complaint, JONES, supra note 10, at 299300; BOULAIS, supra note 10, at 609; see also BODDE \& MORRIS, supra note 9, at 37 , which was less than likely, since a wife who accused her husband was sentenced to three years of penal servitude even if the complaint was found valid, JONES, supra note 10, at 322; BoulAIS, supra note 10, at 644-45. As Bodde and Morris have observed, "nowhere do the tensions of Confucian society emerge more clearly than in the hierarchical differences maintained within the family." BODDE \& MORRIS, supra note 9, at 192.

69. The locus classicus of this sentiment is Confucius' only mention of women in the Analects: "In one's household, it is the women and the [morally] small men that are difficult to deal with. If you let them get too close, they become insolent. If you keep them at a distance, they complain." Confucius, supra note 7 , at 148 .

70. Vivien W. Ng, Ideology and Sexuality: Rape Laws in Qing China, 46 J. ASIAN STUD. 57, 60 (1987) [hereinafter $\mathrm{Ng}$, Rape Laws in Qing China].

71. "E si shi xiao, shi jie shi da." INTER-UNIVERSTTY PROGRAM FOR CHINESE LANGUAGe STUdIES IN TAIPEI ADMINISTERED BY STANFORD UNIVERSITY, SIXIANG YU SHEHUI [THOUGHT AND SOCIETY] 49 (1987). (In Vivien Ng's translation, "It is a small matter to starve to death, but a serious matter to lose one's virtue." $\mathrm{Ng}$, Rape Laws in Qing China, supra note 70, at 60.)

72. "Nizi wu cai, bian shi de." ROBERT H. VAN GULIK, SEXUAL LIFE IN ANCIENT CHINA 374 (1961).

(In Van Gulik's translation, "If a woman has no talents, that is virtue for her." Id. at 249.)

73. Marinus J. Meijer, Homosexual Offenses in Ch'ing [Qing] Law, 71 T'oung PAo 109 (1985) [hereinafter Meijer, Homosexual Offenses in Ch'ing Law].

74. BoUlAIS, supra note 10, at 689; CH'Ü T'UNG-TSU, supra note 9, at 199.

75. JONES, supra note 10 , at 351 ; BoulAIS, supra note 10 , at 688 . 
polygamy was for men only; ${ }^{76}$ although a man could have only one principal wife, ${ }^{77}$ the law placed no limit on the number of concubines. ${ }^{78}$

\section{a. Premarital Sexual Relations}

Traditionally, sexual relations were governed by the Neo-Confucian cult of fidelity and chastity. The cult reached its apogee in the Qing, ${ }^{79}$ with official state sponsorship of virtue and popularization of honors for the virtuous; ${ }^{80}$ chaste women were in effect canonized by Confucian hagiographers. ${ }^{81}$ It is thus not surprising that the Qing code embraced the notion that sexual intercourse was permissible only in marriage, where it could be justified by the filial duty to procreate.

Law did not address premarital sex as a specific category, but it was covered by a general proscription of illicit intercourse, ${ }^{82}$ which had been a punishable offense at least since the promulgation of the $\operatorname{Tang}^{83}$ code $^{84}$ As far as gender equality is concerned, it is notable that the Qing law assigned the same penalty to both parties in cases of illicit intercourse by mutual consent. However, despite this remarkable equality in the law, the woman's real punishment was the loss of her worth as a woman, which rendered her unmarriageable.

\section{b. Extramarital Sexual Relations}

Adultery, in contrast, received a great deal of attention in the law. ${ }^{85}$ Although both marriage and divorce were left largely to self-regulation, the law made divorce mandatory in cases of "breaking the bond" (yi-jue), of which adultery was one instance. ${ }^{86} \mathrm{~A}$ woman's adultery was so grave a transgression

76. There is, nonetheless, anecdotal evidence from earlier periods of women in royal families keeping harems of up to thirty male concubines. See, e.g., ERIC CHOU, THE DRAGON AND THE PHOENLX 22 (1971).

77. JONES, supra note 10, at 125-26; BOULAIS, supra note 10 , at 268 . In an exception to this rule, a man was allowed to marry a second "principal" wife on a deceased brother's behalf if the brother's line would otherwise be extinguished. CHIU, supra note 65 , at 33-35.

78. Concubines' legal status, however, was even lower than that of wives. For instance, a concubine was not allowed to join in the worship of her husband's ancestors, nor could she be worshipped as a member of his lineage after her death. CH'Ü T'UNG-TSU, supra note 9, at 123-37; see also THE TRADITIONAL ChINESE CLAN RULES, supra note 28, at 90.

79. See generally Elvin, supra note 3.

80. BoulaIS, supra note 10, at 304-10; Elvin, supra note 3, at 123-35.

81. On biographies of these "beatified" virtuous women, see GRONEwOLD, supra note 25, at 29.

82. JONES, supra note 10, at 347-48; BOULAIS, supra note 10, at 680; see also Meijer, The Price of a P'ai-lou, supra note 22, at 290.

83. A.D. $618-907$.

84. The T"ANG [TANG] CODE: GENERAL PRINCIPLES 127 (Wallace Johnson trans., 1979); see also MEIJER, supra note 21 , at 39.

85. See supra note 21.

86. Tai Yen Hui, Divorce in Traditional Chinese Law, in ChINESE Family LAW ANd Social Change IN HISTORICAL AND COMPARATIVE PERSPECTIVE, supra note 33, at 91-96. The two other instances of "breaking the bond" were murder and battery of in-laws. For a brief discussion, see also Wong, supra note 
that the law simply did not allow a husband to remain married to his adulterous wife even if he was willing to do so. ${ }^{87}$ Indeed, if he caught his wife and her paramour in flagrante delicto, he could kill both on the spot with impunity. ${ }^{88}$

The Qing code also contained provisions concerning a husband's toleration of his wife's adultery. ${ }^{89}$ These were normally not cases of liberal husbands granting their wives sexual license. Rather, these husbands usually coerced their wives into having sex with other men; poor men with nothing else to sell sometimes prostituted their wives. Yet even in the most flagrant cases of coercion and wife-selling, the law analyzed this in terms of the wife's "adultery" and her husband's toleration of it. Witness the case of a married woman who was sold to an unsuspecting man who married her: both the buyer and the "adulterous" wife received a hundred blows of heavy bamboo."

Magistrates were occasionally willing to adjust the moral maximum required by law when enforcement would have been senseless. For instance, a man who had tolerated his wife's "adultery" with a local bully out of fear was allowed to take her back, even though this "breaking of the bond" would normally have resulted in a mandatory divorce. ${ }^{91}$

Yet, even when underenforced, Qing laws governing marital sexual relations were predicated on a morality of gender inequality; they both reinforced and reflected women's subordination in customary morality.

\section{Prostitution}

Prostitution in the Qing was legal..$^{92}$ For poor men, prostitutes were effectively a substitute for concubines. ${ }^{93}$ Although prostitutes were not criminals, they were nonetheless classified as "mean people" (jianren) in the

65 , at $269-70$.

87. Apart from adultery and other cases of "breaking the bond," the law also recognized seven other conditions allowing - rather than requiring-the husband to divorce his wife (viz. disobedience to the husband's parents, infertility, adultery, loquacity, jealousy, incurable disease, and theft). To be sure, there were "three limits" which could trump any of the seven reasons: the wife had no close relatives to return to, she had completed a "three years' mourning" for her husband's deceased parents, or the husband's family had been poor at the time of the wedding but had since become wealthy. BouLAIS, supra note 10 , at 300-01; Tai Yen Hui, supra note 86, at 84-91. The wife, in contrast, was allowed to bring a suit only if her husband disappeared or mistreated her severely, and even then her husband's consent was required. See supra note 68.

88. JONES, supra note 10 , at 271; BouLAIS, supra note 10, at 546; see also $\mathrm{CH}^{\prime} \mathrm{U}$ T'UNG-TSU, supra note 9 , at 110 . The serious nature of adultery is further illustrated by the case of the father who killed an adulterous daughter: he was acquitted on the grounds that the law prohibited only the "unreasonable" (fei-li) killing of a daughter, and killing an adulterous daughter was not unreasonable. JoNEs, supra note 10, at 304; BOULAIS, supra note 10, at 616-17; see also BODDE \& MORRIS, supra note 9, at 391-94.

89. JONES, supra note 10, at 348-49; BOULAIS, supra note 10, at 684 .

90. BODDE \& MORRIS, supra note 9, at 431-32.

91. Id. at 430 .

92. It was, however, regulated and taxed by the government. GRONEwOLD, supra note 25 , at 27.

93. See, e.g., Fernando HenriQues, Prostitution ANd SocietY: A SURVeY-Primttive, Classical AND ORIENTAL 267 (1962). 
law, ${ }^{94}$ as opposed to "decent people" (liangren). ${ }^{95}$ Indeed, it was often her low class as much as her profession that contributed to a prostitute's opprobrium. Apart from this general classification, prostitutes were frequently slaves without legal rights, ${ }^{96}$ or, even more commonly, adoptive daughters. ${ }^{97}$

While tolerating prostitution in general, the Qing code nonetheless provided penalties for those who forced women into prostitution. ${ }^{98}$ Frequently it was another woman-often a retired prostitute herself-who forced younger women to sell themselves. ${ }^{99}$ The ban on forcing women into prostitution did not, however, extend to husbands who "tolerated" their wives' "adultery" with other men for money, even where in practice it amounted to coercing the wives into prostitution. ${ }^{100}$

Despite a general acceptance of prostitution, the law made it a punishable offense for an official to frequent a prostitute. ${ }^{101}$ However, the law apparently did not prohibit officials from consorting with male prostitutes. ${ }^{102}$ The failure of the Qing to promulgate a categorical prohibition of male

94. CH'Ü T'UNG-TSU, supra note 9, at 129.

95. Sometimes also rendered as "honest people" or "common people."

96. GRONEWOLD, supra note 25, at 32-34. On the status of slaves, see generally Marinus J. Meijer, Slavery at the End of the Ch'ing [Qing] Dynasty, in EsSAYS ON CHINA's LEGAL TRADITION 327 (Jerome A. Cohen et al. eds., 1980).

97. The legal fiction of adoption was in fact one of the main methods of acquiring prostitutes. Yet it was generally little more than fiction; although brothel employees used familial terms of address (mother, sister, aunt, etc.), madams wielded tyrannical authority over their "daughters." See, e.g., 1 DR. JACOBUS $X$, UNTRODDEN FIELDS OF ANTHROPOLOGY: OBSERVATIONS ON THE ESOTERIC MANNERS AND CUSTOMS OF SEMI-CIVILIZED PEOPLES; BEING A RECORD OF THIRTY YEARS' EXPERIENCE IN ASIA, AFRICA, AMERICA AND OCEANIA, BY A FRENCH ARMY SURGEON 65 (Paris, Librairie de Médicine, Folklore et Anthropologie 1898). Many families also used the legal fiction of adoption to disguise the purchase of young girls who would later marry into the family. Even in these cases, the adoptive parents often rented out their future daughter-in-law to prostitution. James McGough, Deviant Marriage Patterns in Chinese Society, in NORMAL AND ABNORMAL BeHAVIOR IN CHINESE CULTURE 171, 191 (Arthur A. Kleinman \& Tsung-Yi Lin eds., 1981). On the wide range of forms and connotations of adoption in Qing China, see GRONEWOLD, supra note 25 , at $38-40$, and infra note 121 and accompanying text.

98. The prescribed penalty was three months in the cangue, one hundred strokes, and three years exile. BoulAIS, supra note 10, at 696. ("[The cangue was] a rectangular collar made of heavy blocks of wood longer from front to back than from side to side. It encircled the neck and rested on the shoulders of the offender, projecting outward in such a way as to prevent him from reaching his face with his hand." BODDE \& MORRIS, supra note 9 , at 95 .)

99. See, e.g., BODDE \& MORRIS, supra note 9, at 512.

100. See supra notes $89-90$ and accompanying text. Some exceptions seem to have existed. For the unusual case of a woman who was praised for refusing to support her husband through prostitution, see Elvin, supra note 3 , at 151 .

101. JONES, supra note 10, at 352-53; BOULAIS, supra note 10, at 691-92. Commoners, however, were not mentioned in the prohibition, and hence officials seem to have been held to a higher standard, rather than given the benefit of relaxed regulation; evidently, noblesse oblige again. See supra note 27. Nonetheless, officials seem to have ignored the prohibition with impunity. See DR. JACOBUS X, supra note 97, at 55.

102. To be sure, Bodde has identified at least one case where an official was charged with frequenting a prostitute of unclear sex. BODDE \& MORRIS, supra note 9, at 435-36. Shen Defu suggests that the prohibition of frequenting female courtesans, first issued in the Ming (A.D. 1368-1644), is one reason why officials turned to male prostitution. SHEN DEFu, WANLI Ye HuO PIAN [WANLI MISCELlanEa] 621 (Beijing reprint ed. 1979), cited in Vivien W. Ng, Homosexuality and the State in Late Imperial China, in HidDen fROM History: ReClaiming the GAY AND LesBian PAST 76, 78 (Martin Duberman et al. eds., 1989) [hereinafter $\mathrm{Ng}$, Homosexuality in Late Imperial China]. 
prostitution was due to neither naïveté nor oversight: such prohibitions had existed in the past, ${ }^{103}$ and the Qing code itself was obviously fully aware of the phenomenon, as it provided penalties for young women and men selling themselves to brothels. ${ }^{104}$ In fact, in 1860 a Western visitor to Tianjin estimated that there were thirty-five male brothels in the city, employing 800 boys in "pederastic prostitution" and catering to clienteles varying from laborers to scholars. ${ }^{105}$ In Nanjing, even a Taoist temple was in the business of renting out its young monks for private entertainment. ${ }^{106}$

Yet, significantly, in the case of male prostitution, a clear distinction was maintained between socio-sexual roles: Little or no stigma attached to the patrons in the sexually active role, whereas the prostitutes in the sexually passive role were strongly censured in the public opinion, ${ }^{107}$ apparently because they were seen as taking on a female cultural role.

In short, the tolerance of both female and male prostitution suggests a general laissez-faire attitude to male sexuality. Much as the law left marital affairs largely to self-regulation by the clan, so it also interfered only minimally with prostitution. ${ }^{108}$ The law respected the right of men to buy sex from women, and even from men, while women, as well as men in "female" sexual roles, were expected to provide the services needed. Prostitution was hence another area of legal and social gender inequality.

103. A highly developed system of male prostitution existed in the Song (A.D. 960-1279). See, e.g., Bret Hinsch, Passions of the Cut Sleeve: The Male homoseXual Tradition in China 93-97 (1990). An imperial decree prohibited male prostitution from A.D. 1111-1117, but it seems not to have been regularly enforced. JACQUES GERNET, DAILY LIFE IN CHINA ON THE EVE OF THE MONGOL INVASION, 1250-1276, at 99 (H.M. Wright trans., 1962).

104. BoULAIS, supra note 10 , at 696 .

105. LAWRENCE E. GiCHNER, ERotiC ASPECTS OF ChINESE Culture 76 (1957), quoted in HiNSCH, supra note 103, at 152. Male prostitution was equally prevalent in Beijing and Canton. See, e.g., DR. JACOBUS X, supra note 97, at 117; C.A. SCHLEGEL, LA PROSTITUTION EN ChINE (1880), cited in HENRIQUES, supra note 93 , at 260.

106. ORIENTAL Dally NewS, Jan. 10, 1985, \& 25, cited in Ruan Fang-fu \& Tsai Yung-mei, Male Homosexuality in Traditional Chinese Literature, 14 J. HOMOSEXUALITY 21, 27 (1987).

107. HINSCH, supra note 103, at 94-95. Usually homosexual relations seem to have been ordered hierarchically, with the younger and socially subordinate partner in the sexually "passive" role, i.e., as the object of penile penetration. Id. at 9-10. It is noteworthy that also in the West in "trans-genderal" same-sex relationships, the gender-conforming partner is frequently considered "normal" while the gender-subverting masculine woman or effeminate man is viewed as "queer." See, e.g., Esther Newton, The Mythic Mannish Lesbian: Radclyffe Hall and the New Woman, 9 SIGNS 557 (1984); George Chauncey Jr., Christian Brotherhood or Sexual Perversion? Homosexual Identities and the Construction of Sexual Boundaries in the World War One Era, 19 J. Soc. HIST. 189 (1985) (analyzing the behavior of sailors at Newport Naval Training Station who engaged in sex with men they viewed as "queer" while maintaining an image of themselves as "normal").

108. Where the court of public opinion was thought too weak, clan rules often provided for sanctions for fathers who allowed their sons to frequent prostitutes. See, e.g., the rules of a typical Hebei clan in VAN DER SPRENKEL, supra note 19, at 82-83. 


\section{Homosexual Relations}

Traditionally, male homosexuality was tolerated, even accepted, at least among the elites, ${ }^{109}$ as long as it did not interfere with one's procreative obligations; ultimately there was "no crime ... more grave than that of filial impiety,"110 and not having offspring was considered the worst form of filial impiety, as it meant that one's ancestors would have no one to continue to sacrifice to them. Indeed, clan rules sometimes contained explicit sanctions for confirmed bachelors. ${ }^{111}$ Nevertheless, in the traditional categorization of sexual sins, sexual relations with other men were not a particularly serious offense. ${ }^{112}$

Although the combination of Neo-Confucianism and Manchu puritanism ${ }^{113}$ seems to have increased objections to homosexuality in the Qing, ${ }^{114}$ those objections were generally designed to confine all sexual activity to marriage, rather than to condemn homosexuality itself. ${ }^{115}$ The prevalent attitude is exemplified by the case of a man who accidentally strangled his male lover while making love to him; he was rather

109. For example, several Han (206 B.C.-A.D. 220) emperors, including the martial Han Wudi, were known for their dalliances with male favorites. For a table of these emperors and their favorites, see Ruan Fang-fu \& Tsai Yung-mei, supra note 106, at 23. The classical literary allusion to homosexuality, "passion of the cut sleeve," in fact originates in Emperor Ai's devotion to Dong Xian, his beloved: The Emperor woke from a nap and wanted to get up, but Dong Xian was sleeping stretched out across his sleeve, so the Emperor cut off his sleeve so as not to disturb his lover. See DUANXIU PIAN [WRITINGS ON THE CUT SLEEVE] 9.5B (Wuxia Ameng ed.) (a collection by an anonymous author of some fifty famous "case histories" of homosexuality), quoted in HINSCH, supra note 103, at 53. Sima Qian, the father of Chinese historiography, attested that "it is not women alone who can use their looks to attract the eye of the ruler; courtiers and eunuchs can play at that game as well. Many were the men of ancient times who gained favor this way." 2 SSUMA CH'IEN [SIMA QIAN], RECORDS OF THE GRAND HISTORIAN OF CHINA 462 (Burton Watson trans., 1961), quoted in HINSCH, supra note 103, at 36. On homosexuality in the Han in general,

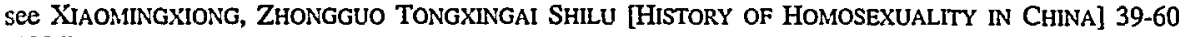
(1984).

110. XIaojing Zhushu [COMmentary on the Classic of Filial PIETY] 6.2A, quoted in Ch'ü T'UNG-TSU, supra note 9, at 42 .

111. The Traditional Chinese Clan Rules, supra note 28 , at 78 .

112. WOLFram EBERHaRd, GUILT AND Sin IN TRAdITIONAL ChINA 61-65 (1967).

113. The increasing puritanism of Qing culture in general has been noted by several historians. See, e.g., HiNSCH, supra note 103, at 162 (attributing Qing puritanism "to a more stringent application of Neo-Confucian rhetoric regarding the family, imported Manchu concepts of sexuality, and a reaction against individualistic Ming permissiveness"); VAN GULIK, supra note 72, at 222-28 (describing Neo-Confucian zealotry in general, e.g., efforts by Zhu Xi, the father of Neo-Confucian orthodoxy, to bowdlerize even the love songs in the Book of Odes by reinterpreting them as political allegories, id. at 223); $\mathrm{Ng}$, Rape Laws in Qing China, supra note 70, at 59 (analyzing the intensification of state support for the cult of chastity and interpreting it as "part of the Qing effort to sponsor their own Confucian renewal, in order to convert conservative Chinese scholars to the side of the Qing government").

114. For instance, the Kangxi Emperor was so displeased with his son's male lovers that he had three of them executed. JONATHAN D. SPENCE, EMPEROR OF CHINA: SELF-PORTRAIT OF K'ANG-HSI [KANGXI] at $\mathrm{xxi}, 125$ (1975).

115. As to the general acceptability of homosexual relations even in the late Qing, Van Gulik notes that "social etiquette of that time was rather tolerant to the public manifestation of these relations (men walking hand in hand in the streets, presence of catamites at theatrical performances, etc.)." VAN GULIK, supra note 72, at 48 n.2. On homosexuality in the Qing in general, see XIAOMINGXIONG, supra note 109, at $157-250$. 
matter-of-factly charged with "killing in play" (xisha), not with deviant sexual behavior. ${ }^{116}$

Yet in 1740 a substatute ${ }^{117}$ on male rape ${ }^{118}$ was added to the Qing code, one of whose provisions also made "consensual sodomy" (hetong jijian) between two men an offense punishable by one month in the cangue and one hundred blows of heavy bamboo. ${ }^{119}$ However, the actual enforcement of the law seems to have been selective; once again, male sexuality was allowed to transgress the bounds of legal norms. ${ }^{120}$

The legal fiction of adoption also provided a way for men to legitimate homosexual relations; adoption in the Qing had expansive connotations of deep friendship and even of marriage, ${ }^{121}$ so that two men could be bound together by the fictive kinship between a "bond elder brother" (qixiong) and "bond

116. Meijer, Homosexual Offenses in Ch'ing Law, supra note 73, at 112; JONES, supra note 10, at 278; BoulaIS, supra note 10 , at 564 . In evidently intense erotic excitement, the silk belt of the defendant's trousers became fastened around his lover's neck and strangled him when the men fell off the bed.

117. On the distinction between statutes and substatutes, see supra note 10.

118. Remarkably enough, the substatute governing "forcible sodomy" (qiangxing jijian) treated all rapists comparably, regardless of the gender of their victim; the penalties prescribed depended entirely on the number of assailants, the degree of violence used, and the age of the victim. ERNEST ALABASTER, NOTES AND COMMENTARIES ON CHINESE CRIMINAL LAW 368 (London, Luzac \& Co. 1899). For instance, intercourse with a boy of 12 years of age or younger was deemed statutory rape, just as intercourse with a girl of 12 years of age or younger was. Boulais translates only part of the substatute. BoulAIS, supra note 10, at 681-82. For a complete English translation, see Meijer, Homosexual Offenses in Ch'ing Law, supra note 73 , at 110 , and HINSCH, supra note 103 , at $143-44$.

Even more surprisingly, a double standard that deprived women with "indecent" pasts of full legal protection seems to have extended to the victims of male rape as well, The law on gang male rape, for instance, provides penalties only for the rape of "sons and younger brothers of decent citizens [liangren]." Meijer, Homosexual Offenses in Ch'ing Law, supra note 73, at 110. In an 1815 case, when the victim of male rape was discovered to have a history of previous homosexual relations, he was deemed not to be a "decent man," the rapist's sentence was reduced, and the victim was punished for consensual sodomy. $\mathrm{Ng}$, Rape Laws in Qing China, supra note 70, at 69. Similarly, a young man who killed the man attempting to rape him was given no leniency since he had earlier slept with the man voluntarily and was thus no longer "decent." Meijer, Homosexual Offenses in Ch'ing Law, supra note 73, at 127.

However, that the sexual double standard was applied "equally" to both male and female victims of rape may prove too much to the extent that it suggests a semblance of genuine sexual equality. In the end, it is not an instance of women being judged by the same general standards of sexual morality as men, but rather of a small group of men being judged by the much more exacting standard of chastity for women. Moreover, the sexually passive role of male rape victims defined them as essentially female in the traditional conception of sexual dynamics, which evidently made them more liable to be held to the higher standard of female virtue; since raped men could effectively be analogized to women, much like male prostitutes, see supra note 107 and accompanying text, it was deemed appropriate to subject them to the same double standard as women.

Indeed, not all Qing magistrates seem to have been wholly convinced that victims of male rape had assumed their passive sexual role involuntarily. Much as in the case of female rape, there is often a lingering suspicion that the victim himself may be to blame. "A man who simply agrees to sleep with another man whom he does not know, seems to be a doubtful sort of man," opined the Board of Punishments of a young man who had accepted an invitation to spend the night at a friend's house where his friend then raped him. Meijer, Homosexual Offenses in Ch'ing Law, supra note 73, at 126.

119. Boulais, supra note 10 , at 682 . (On the cangue, see supra note 98 .)

120. HINSCH, supra note 103 , at 140 .

121. In Hinsch's words, adoption ( $q i)$ in the Qing was "a much more complicated and diverse social act than its Western equivalent," for it had multiple connotations of "contractuality, deep friendship, and adoption." Id. at 131. On the varied uses of adoption and the functional convergence of adoption and marriage, see McGough, supra note 97, at 188, 198. 
younger brother" (qidi). ${ }^{122}$ An important consequence of the private nature of marriage in the Qing was that, despite official disapproval, actual same-sex marriages were possible in areas where local communities were willing to sanction them. Preeminent among these areas was Fujian, whose local dialect in fact had a number of nonderogatory designations for men who preferred romantic liaisons with members of their own sex. ${ }^{123}$ These marriages imitated carefully the heterosexual analogue, ${ }^{124}$ including even bride prices for young boys. ${ }^{125}$ Although the unions were often long-lasting, up to twenty years and even longer, most eventually dissolved because of the filial duty to procreate. ${ }^{126}$

Despite the recognized existence of male homosexual relations in the Qing ${ }^{127}$ and of a relatively tolerant atmosphere for the expression of male

122. SHEN DEFU, supra note 102 , at 903 , quoted in $\mathrm{Ng}$, Homosexuality in Late Imperial China, supra note 102 , at $85-86$. Attesting to the quasi-marital nature of these adoptions, Mitamura notes that "[w]hen a ch'i hsung [qixiong] went to the home of a ch'i ti [qidi] he was welcomed by the whole family as if he were a bridegroom. If the $c h$ ' $i t i$ were later to marry, the $c h$ ' $i$ hsung would pay all the expenses." TAISUKE Mrtamura, Chinese Eunuchs: The Structure of InTIMATE Politics 64 (Charles A. Pumeroy trans., 1970).

123. DR. JACOBUS $X$, supra note 97 , at 115 . The men of Fujian had a national reputation for nanfeng, or the "southem custom"-yet another Chinese euphemism for homosexuality. See, e.g., HiNSCH, supra note 103, at 120, 130-33. Shen Defu also attests that "[t]he Fujianese especially favor male homosexuality. This preference is not limited to any particular social or economic class, but the rich tend to cavort with the rich, and the poor with the poor." SHEN DEFU, supra note 102, at 903, quoted in $\mathrm{Ng}$, Homosexuality in Late Imperial China, supra note 102, at 85.

124. Li Yu expains: "In Fujian the southern custom [nanfeng] is the same as that for women. . . . They do not skip the three cups of tea or the six wedding rituals-it is just like a proper marriage with a formal wedding." LI YU ZHUANII [COLLECTED WORKS OF LI YU] 5406 (Helmut Martin ed., 1970), quoted in HINSCH, supra note 103, at 127. On Fujian style homosexual marriagés in general, see id. at 127-33.

125. "[I]n Fujian, virginity is very important for homosexuals, just as much as it is for women. There is a distinction between first marriage and remarriage. If [the youth] is a virgin, people will pay a heavy betrothal price for him, and all the proper wedding rituals are observed." LI YU ZHUANI, supra note 124, at 5406-07, quoted in $\mathrm{Ng}$, Homosexuality in Late Imperial China, supra note 102, at 82 . The price was determined in much the same way as in the heterosexual context: "But if a parent's vigilance is lax, and the youth has already been deflowered, he will be regarded as 'rotten willow and withered flower.' Even though he may not be considered trash, and may still find someone willing to pay for him, his parent no longer has any say about the price." Id.

126. HINSCH, supra note 103 , at 132 .

127. Although the prevalence of male homosexuality in the Qing is impossible to gauge with any certainty, there is anecdotal evidence of "the seduction of young boys or young men by their Confucian teachers and seduction of neophytes by Buddhist monks," for instance. $\mathrm{Ng}$, Rape Laws in Qing China, supra note 70, at 68. See, e.g., the summary of $A$ Chronicle of True Love, a story of a young student's seduction by his teacher, in $\mathrm{Ng}$, Homosexuality in Late Imperial China, supra note 102, at 84 . See also supra note 106 on Taoist monks' sexual proclivities. Western observers of China were also acutely aware of-and morbidly fascinated by-the unspeakable crime contre nature (in Boulais's euphemistic translation of the Qing Code, BoulaIS, supra note 10, at 681-82), of which they frequently spoke at great length. See, e.g., supra note 105 and accompanying text, for observations on male brothels in Tianjin. An indignant British visitor to China complained that "[t]he commission of this detestable and unnatural act is attended with so little sense of shame, or feelings of delicacy, that many of the first officers of state seemed to make no hesitation in publicly avowing it. Each of these officers is constantly attended by his pipe-bearer, who is generally a handsome boy from fourteen to eighteen years of age, and is always well dressed." SIR JOHN BARROW, TRAVELS IN CHINA 149-50 (1806), quoted in HENRIQUES, supra note 93, at 250. Moreover, the existence of legal regulations on male prostitution, see supra note 104, male rape, see supra note 118, and even consensual sex between men, see supra note 119, suggests that male homosexual relations were indeed relatively common and their existence recognized. 
homosexuality, the Chinese tradition is conspicuously silent on female homosexuality, except for occasional suspicions that nuns engage in lesbian activities. ${ }^{128}$ To be sure, women had far fewer opportunities to explore their sexuality and to form intimate relationships with women outside their households. As a consequence, lesbian relationships frequently took place between wives and concubines. ${ }^{129}$

However, there are accounts of localized marriage resistance in certain areas, most notably in Guangdong, ${ }^{130}$ from the late nineteenth century through 1935, and of lesbian group marriages based, again, on the heterosexual model and complete with all its rituals. ${ }^{131}$ Yet the phenomenon, caused by a surge of foreign investment in sericulture, was specific to the Pearl River Delta in Southern Guangdong. Industrial development in the region made it possible for some women to "make a fair living by unwinding the fine threads of the silk-worm cocoons" in new factories; ${ }^{132}$ unlike most Chinese women, these economically emancipated spinsters-literal ones-could afford to refuse to marry. However, the public viewed the Guangdong marriage resistance movement as a threat to men and a serious moral problem. ${ }^{133}$ The phenomenon seems thus to have been largely aberrational. ${ }^{134}$

128. For a brief general discussion of lesbianism in China, see HINSCH, supra note 103, at 173-78, and sources cited therein. One obvious reason for the paucity of sources is that literary pursuits were traditionally reserved for men who wrote for male audiences.

129. See The Traditional Chinese Clan Rules, supra note 28, at 109. Sex segregation within the household further limited women's contact with males. See id. at 93-95. Li Yu's story of a woman who succeeds in having her husband take her female lover as a concubine is one of the few literary treatments of lesbianism in the Chinese tradition. See Lian Xiang Ban [Pitying the Fragrant Companion], in LI YU ZHUANI, supra note 124 , cited in VAN GULIK, supra note 72 , at 302.

130. See generally Andrea Sankar, Sisters and Brothers, Lovers and Enemies: Marriage Resistance in Southern Kwangtung [Guangdong], 11 J. HoMoSEXUALITY 69 (1985); Helen F. Siu, Where Were the Women? Rethinking Marriage Resistance and Regional Culture in South China, LATE IMPERIAL CHINA, Dec. 1990, at 32; Marjorie Topley, Marriage Resistance in Rural Kwangtung [Guangdong], in WOMEN IN CHINESE SOCIETY 67 (Margery Wolf \& Roxane Witke eds., 1975). See also MAGNUS HIRSCHFELD, MEN AND WOMEN: THE WORLD JOURNEY OF A SEXOLOGIST 81 (1935); McGough, supra note 97, at 185-86.

131. Some of the lesbian couples in Southern Guangdong even adopted female children who in tum could inherit family property from the couple's parents. HU PU'AN, 2 ZHONGHUA QUANGUO FENGSU ZHI [GAZETTEER OF CHINESE CUSTOMS] 34 (reprint ed. 1968), cited in McGough, supra note 97, at 186. The women in the marriage resistance movement usually formed sworn sisterhoods of five to six members. However, not all the women involved were lesbian; many simply wanted to flee the tyranny of marriage. Nonetheless, every sworn sister had to take a vow of chastity; sexual relations with men were regarded as "the single worst transgression a sou hei [here, sworn sister] could make." Sankar, supra note 130, at 76. Although accounts are often vague, there is no doubt that many of the women were in fact lesbian. In the words of one distraught male observer, "it is difficult for a gentleman to speak of it," yet the same gentleman dutifully records that, "[a]s far as [the women's] cohabitation is concerned, though they cannot completely live as man and wife, yet they can actually have the pleasure that men and women do, either through massage and caresses, or through using mechanical aids." HU PU'AN, supra, at 34, quoted in McGough, supra note 97 , at 186.

132. HIRSCHFELD, supra note 130 , at 81 .

133. Sankar, supra note 130 , at 76 .

134. To be sure, apart from the marriage resistance movement, there are also accounts of certain female "homosocial" phenomenona, with possibly erotic undertones, such as gentry women constructing a private female discourse through letter-writing, a traditional male occupation. See generally Ellen Widmer, The Epistolary World of Female Talent in Seventeenth-Century China, LATE IMPERIAL CHINA, Dec. 1989, at 1 . On "homosociality" and the ambiguity between identification and desire that it connotes, see generally 
In sum, Qing law did register its disapproval of male homosexual relations, but the moral maximum was adjusted somewhat in practice. Making sure that sons married was left largely to regulation by the more flexible clan rules. Homosexuality remained relatively acceptable for men as long as they eventually married, although even in male-male relations the socioculturally "feminine" partner occupied a lower position, suggesting truly pervasive gender bias. ${ }^{135}$ Female homosexuality, in contrast, was conspicuous by its absence in both legal and popular discourse. In practice, then, men's sexual expression was restricted far less than that of women.

\section{B. Sex Offenses in the PRC: A Call for Gender Equality}

In stark contrast to the Qing, PRC laws governing marital transgressions (pre- and extramarital affairs), prostitution, and homosexual relations are governed by the principle of gender equality. Yet, as moral principles rather than legal directives, these laws have been manipulated and compromised; the gap between the letter of the law and legal reality in the area of sex offenses appears in fact to be greater in the PRC than in Qing China.

\section{Marital Transgressions}

The PRC has declared the "fundamental negation of the old society's feudalistic system of marriage and the family" as one of its main goals. ${ }^{136}$ A commentary on the Marriage Law of 1980 declared the main functions of family to be "the organization of living and consumption, family planning, reproduction, and the education of succeeding generations." 137

In the new family and new marriage, not only are PRC women equal in the law, as proclaimed by the Constitution, ${ }^{138}$ but in some respects even "more" equal than men. While the Marriage Law of 1980 provides for general

EVE KOSOFSKY SEdGWICK, BETWEEN MEN: ENGLISH LITERATURE AND MALE HOMOSOCIAL DESIRE (1985). For the view that bonds between women constitute a "lesbian continuum" of homoerotic feeling, see Adrienne Rich, Compulsary Heterosexuality and Lesbian Existence, 5 SIGNS 631 (1980).

135. Even when male homosexual relations were accepted, the acceptance was generally limited to the person in the "active" sexual role. See supra note 107. Again, as in the case of male prostitutes, by an extension of the symbolic logic of the heterosexual male-female hierarchy, the sexually passive male seems to have been condemned for engaging in culturally feminine behavior and for voluntarily participating in women's subordinate status. That usually the junior and socially inferior party took the passive sexual role indicates a further correlation between "female" behavior and low status.

136. LECTURES ON THE CRIMINAL LAW, supra note 33, at 86.

137. L. ZhONGFANG ET AL., HUNYINFA GAILUN [AN INTRODUCTION TO THE MARRIAGE LAW] 134 (1984), quoted in Michael Palmer, The People's Republic of China: Some General Observations on Family Law, 25 J. FAM. L. 41, 42-43 (1986-87).

138. XIANFA (1982) [Constitution], art. 48, translated in THE CONSTITUTION OF THE PEOPLE'S REPUBLIC OF CHINA, supra note 57. Similarly, both the Constitution and the Marriage Law make family planning the responsibility of both husband and wife. Id. art. 49; Marriage Law of 1980, supra note 54, art. 2. 
gender equality in marriage, a husband's right to divorce is restricted when the wife is pregnant. ${ }^{139}$

Moreover, the definition of marriage is more restrictive than in the Qing. Polygamy, or bigamy, as the Criminal Law puts it more modestly, is strictly illegal, ${ }^{140}$ although in practice it persists and seems to be on the increase, ${ }^{141}$ largely for traditional reasons: recent economic reforms have created pockets of prosperity, and men of wealth can afford to support more than one woman.

\section{a. Premarital Sexual Relations}

The legal status of premarital sexual relations in the PRC is unclear. The Minister of Public Health asserted confidently in 1987 that casual sex-as well as homosexuality -is against the law, but the Minister of Justice voiced his disagreement. ${ }^{142}$ Although PRC laws do not address premarital sex directly, the "hooliganism" provisions of the Criminal Law, for example, can be construed to cover premarital sexual experimentation. ${ }^{143}$ Indeed, whatever the official position may be, there have been practical efforts to enforce premarital abstinence: In the 1980's, security patrols were organized in urban parks to reprimand and sometimes arrest unmarried couples caught in compromising situations in secluded spots. ${ }^{144}$

In the absence of a case-reporting system, not only is it unclear what exactly the legal norm on premarital sex is in the PRC, but also how evenhandedly that norm is applied to the different sexes. That reports on the legal enforcement of abstinence are relatively rare suggests, however, that premarital sex is more commonly left to social rather than legal regulation.

139. Marriage Law of 1980 , supra note 54, art. 27. Furthermore, both the Criminal Law and Criminal Procedure Law protect pregnant women from the death penalty. Criminal Law, supra note 33, art. 44; Criminal Procedure Law, supra note 40, art. 154.

140. Criminal Law, supra note 33, art. 180.

141. See, e.g., Getihu Chonghun Fanzui Wenti Tuchu [An Obvious Problem of Bigamy in Self-Employed Households], 1949 ZhONGGUo FAZHI BAO [ChINA LEgAL SYSTEM NewS], Sept. 18, 1987, at 2, cited in Michael Palmer, The People's Republic of China: Problems of Marriage and Divorce, $27 \mathrm{~J}$. FAM. L. 57, 72 (1988-89). However, most cases of bigamy probably go unreported. This is even more likely in rural areas where public security bureaus exist in name only and no other enforcement mechanisms exist. See, e.g., Li Deshun, Why Women Become Commodities, SHEHUI [SOCIETY], Sept. 20, 1990, at 4-5, translated in JoINT PubliCATIONS RESEARCH SERVICE-REPORT: CHINA, Jan. 16, 1991, at 79.

142. Beijing Denies Man Was Ousted over Sex, S. CHINA MORNING POST, Aug. 27, 1987, cited in Jerome A. Cohen, Sex, Chinese Law and the Foreigner, 18 H.K. L.J. 102, 102 n.2 (1988).

143. Supra note 47 and accompanying text. In the words of one commentator, "if a woman has illicit sex with another person ... for satisfying some perverted sexual desire, and if the conduct is purely debauchery in nature, it is . . . [a crime] of hooliganism," with illicit sex apparently qualifying as "perverted sexual desire" by definition. Chen Yehong, On Prostitution and the Application of Criminal Law, Huazhong Shifan DaXue XuEBao [JouRnal of CENTRAL CHINA NoRMaL UNIVERSITY], Dec. 1, 1990, at 35-40, translated in JoINT PUBlications RESEARCH SERVICE-REPORT: ChINA, Jan. 31, 1991, at 65, 68 (asserting also that "[1]icentious acts are acts of hooliganism which falls [sic] under the crime of hooliganism in the criminal law and should be punished as such," id. at 70).

144. See, e.g., Emily Honig \& Gall.Hershatter, Personal VoICes: Chinese Women in the 1980's 116 (1988). 
In contrast to the law, the social norms are quite unambiguous: Despite all the official proclamations of gender equality in the laws and calls for a more egalitarian concept of chastity, ${ }^{145}$ the traditional cult of female chastity continues to structure marital and premarital relations. For instance, newspaper columns addressing premarital sex teach young women how best to fend off advances, while the advice for young men focuses on whether or not magnanimity requires that one forgive one's girlfriend for having slept with someone else. ${ }^{146}$

In practice, then, traditional social norms in favor of men's sexual liberty seem to trump legal norms. This also suggests that when law enforcers do choose to view premarital sex as "hooliganism," they are more likely to pursue female than male offenders. To be sure, these catch-all provisions may occasionally apply to men as well. A young man who flirted with four women and engaged in sex with two of them is a case in point: of four legal commentators on the case, only one believed that he should not be punished for "hooliganism" merely because his behavior, although immoral, was not strictly illegal. ${ }^{177}$

\section{b. Extramarital Sexual Relations}

Insofar as extramarital affairs are concerned, the Qing notion that intercourse should be limited to marriage persists as the prevalent social norm in the PRC as well. The legal implications of extramarital sexual activity, however, are as ambiguous as those of premarital sex. While technically extramarital affairs appear not to constitute a crime, they may be subject to administrative discipline under the Security Administration Punishment Act, ${ }^{148}$ whose sanctions are often the same, or worse, than those of the

145. See, e.g., Liu Dalin, Fouding Zhencao, Tichang Zhongzhen [Negate Chastity, Promote Loyalty], NÜZI SHIJIE [WOMEN's WORLD], May, 1985, at 21, quoted in HONIG \& HERSHATTER, supra note 144, at 121. It is noteworthy that the article does not call for the general abolition of the concept of chastity but only for its more equal application to require chastity from both women and men.

146. HONIG \& HERSHATIER, supra note 144, at 116. Recent liberalization notwithstanding, even the young remain ambivalent. In one poll, almost two-thirds of university students who professed to be ready to discard traditional sexual morality still maintained that "the chastity of a virgin is sacred." BAOKAN WENZHAI [PERIODICAL DIGEST], Aug. 27, 1985, quoted in HONIG \& HERSHATTER, supra note 144, at 116. In another survey, college students were presented with the proposition that "If two people love each other, it is okay to have sex," and around $20 \%$ of the respondents found the notion "acceptable," while about onethird characterized it as "absurd" and another one-third as "unacceptable." Yang Huiru et al., The Impact of Western Philosophical Ideas on Today's College Students, ZHENGMING [CoNTENDING], Jan. 15, 1991, at 76, translated in JoINT PUBLICATIONS RESEARCH SERVICE-REPORT: CHINA, June 24, 1991, at 4, 5.

147. Ta Yingdang Shoudao Shenme Fating de Shenpan? [What Court Should Judge Him?], MinzHU YU FAZHI [DEMOCRACY AND THE LEGAL SYSTEM], Jan. 1982, at 20.

148. "Adultery is not a crime in China, but it is conduct condemned by public opinion and social morals and may be subject to administrative discipline." Chen Yehong, supra note 143, at 69 . The authors of a recent sex survey also maintained that "by the moral and legal norms of contemporary society, only sexual activity limited to marriage is normal." Shanghai Xing Shehuixue Yanjiu Zhongxin [Shanghai Sexual Sociology Research Center], Xiandai Zhongguoren de Xing Wenti: Yi fen Quanguo "Xing Wenming" Diaocha Baogao [Sexual Problems of Today's Chinese: Report on Nationwide Survey of "Sexual Culture"], 
Criminal Law. ${ }^{149}$ Some have suggested that adultery indeed be made a crime, ${ }^{150}$ and at least Shanghai has used local regulations to brand extramarital affairs as "semi-criminal."151 There are reports of women who had extramarital affairs and were consequently sent to reeducation-through-labor camps, ${ }^{152}$ apparently under the Security Administration Punishment Act, but at the same time many-in cities, mostChinese seem to believe that the regulation of extramarital affairs should be left to the parties concerned, much as in the Qing. ${ }^{153}$

The new Marriage Law of 1980 has brought extramarital affairs more into the open, or as one PRC observer put it, rather more melodramatically, "[new] notions about marriage held by gaudily dressed men and women have merged into a hurricane that is hitting every family."154 The Law makes alienation of affection a legitimate ground for divorce, ${ }^{155}$ and courts often, though by no means always, consider extramarital affairs evidence of alienation of affection. ${ }^{156}$ Before the new law, admitting to extramarital affairs frequently had serious consequences, even for men, as in the case of a man who was severely criticized by his work unit, removed from his administrative duties, and placed on probation by the Party. ${ }^{157}$ Today, however, approximately one third of the divorces are attributed to "third parties" (disanzhe). ${ }^{158}$

Unsurprisingly, not all extramarital affairs are created equal; much depends on who is having sex with a "third party." The press rarely publishes reports of married women's involvement with other men. ${ }^{159}$ It focuses on men's extramarital adventures instead, typically with younger women portrayed as

MinZHU Yu Fazhi [DEMOCRACY AND tHe LeGAL SySTEM], Oct. 1990, at 32 [hereinafter Chinese Sex Survey].

149. Moreover, administrative sanctions do not have even the minimal, if often ignored, procedural safeguards provided by the Criminal Procedure Law. On the nature of administrative sanctions in general, see Note, Concepts of Law in the Chinese Anti-Crime Campaign, 98 HARv. L. REv. 1890, 1898-1902 (1985), and LAWYERS COMMITTEE FOR HUMAN RIGHTS, supra note 51, at 66-76.

150. See, e.g., Fang Xiang, Jianyi Guiding Tongjianzui [Suggesting That Adultery Be Made a Crime], MINZHU YU FAZHI [DEMOCRACY AND THE LEGAL SYSTEM], Mar. 1984, at 18.

151. ShEhUi BAO [SOCIETY NEwS], June 13, 1985, at 1, cited in HONIG \& HeRSHATTER, supra note 144 , at 221.

152. Bao Ning, Divorce: A Skewed Social Phenomenon, SHEHUI [SOCIETY], Dec. 20, 1990, at 29-31, translated in JoINT PUbliCATIONS ReSEARCH SERVICE-REPORT: CHINA, Apr. 24, 1991, at 97. On PRC labor camps, see, e.g., LASZLo LADANY, LAW AND LEGALITY IN CHINA 111-31 (1992).

153. Of married couples surveyed, about $54 \%$ in the cities and $44 \%$ in the country "understand" or "don't see a need to interfere with" extramarital affairs. Chinese Sex Survey, supra note 148, at 33.

154. Bao Ning, supra note 152, at 97.

155. Marriage Law of 1980 , supra note 54 , art. 25.

156. Wu Wenzao, You Guanyu Lihun Anjian de Ji ge Wenti [Some Problems Concerning Divorce Cases], Shehui KeXUe [SOCIAL SCIENCE], May 1982, at 53, cited in HoNig \& HershatTER, supra note 144 , at 220.

157. Why Our Marital Relationship Has Broken Dovm, ChINESE SOC. \& ANTHROPOLOGY, Spring 1975, at 7, cited in HONIG \& HERSHATTER, supra note 144, at 219.

158. Bao Ning, supra note 152, at 98 .

159. However, one relatively recent survey suggested that urban married women have the highest rate of extramarital affairs. Lu Guoli, Four Contradictions in Marriage in China, ZHONGGUO SHEHUI BAO [CHINA SOCIETY NEWS], July 30, 1991, at 3, translated in JoINT PUblications ResearCH SERVICE-REPORT: CHINA, Oct. 11, 1991, at 68. 
calculating sirens, and thereby reminds married women of the importance of catering to their husbands so that they will not be tempted to look for satisfaction elsewhere. ${ }^{160}$

Much as in the case of premarital sexual relations, traditional social norms continue to impose a higher standard of chastity on women than men. Again, despite the relative paucity of reports on the legal enforcement of marital fidelity, it seems plausible that the traditional bias in men's favor informs law enforcement as well. In fact, many of the available reports on "adulterers" subjected to administrative discipline concern female violators. ${ }^{161}$

In the end, however, gender equality constitutes the official legal morality in marriage, whether or not always enforced; although it is not always clear what conduct the law in fact prohibits, on its face it is gender-neutral.

\section{Prostitution}

The Criminal Law of the PRC, promulgated in 1979, criminalized both the "forcing"162 and "luring"163 of women into prostitution, but did not make prostitution itself illegal. ${ }^{164}$ This, however, was not an expression of liberality. Rather, it suggests the extent to which the vision of the drafters of the law was limited by the traditional scenario in which women were almost invariably forced into prostitution. The Criminal Law was noteworthy for not providing penalties for the patronage of prostitutes either. ${ }^{165}$

Significant increases in the incidence of prostitution ${ }^{166}$ finally prompted the promulgation of the Prostitution Provisions in 1991, which explicitly criminalized both the act of prostitution itself as well the patronage of

160. HONIG \& HERSHATTER, supra note 144 , at 222-23.

161. See, e.g., supra note 152 and accompanying text.

162. Criminal Law, supra note 33, art. 140.

163. Id. art. 169. To emphasize its resolve in cracking down on prostitution, in 1983 the Standing Committee of the National People's Congress raised the maximum penalties for prostitution-related crimes. Quanguo Renmin Daibiao Dahui Changwu Weiyuanhui Guanyu Yancheng Yanzhong Weihai Shehui Zhi'an de Fanzui Fenzi de Jueding [Decision of the Standing Committee of the National People's Congress Regarding the Severe Punishment of Criminal Elements Who Seriously Endanger Public Security], 1983 Fagui Huibian 65, reprinted and translated in THE CRIMINAL LAW AND THE CRIMINAL PROCEDURE LAW OF THE PEOPLE'S REPUBLIC OF CHINA, supra note 33, at 241-42.

164. Nonetheless, even prostitutes not overtly coerced into prostitution have been punished for "hooliganism." Chen Yehong, supra note 143, at 66.

165. The Security Administration Punishment Act promulgated in 1986 made prostitution itself as well as the patronage of prostitutes offenses subject to administrative, but not criminal, sanctions; the Act was hence applicable only in cases where the circumstances were not serious. SAPA, supra note 44, art. 30 . According to one commentator, "[i]f one is truly hard-pressed and is forced into occasional prostitution, and if one is not making a lot of money, and if the mistake can be rectified with education, or if the circumstances are not serious, the person should be dealt with according to the [SAPA] and not the criminal law." Chen Yehong, supra note 143, at 69.

166. For instance, from January to July 1991, there were 26,751 reported cases of prostitution in the cities and 23,865 in the countryside, representing an increase of $75.2 \%$ and $40.2 \%$, respectively, over the same period in 1990. Yang Xiaobing, China Launches Anti-Prostitution Campaign, BEIING REV., Dec. 16, 1991 , at 27. 
prostitutes. ${ }^{167}$ As a justification for making prostitution itself a crime, the publicizers of the Provisions emphasized the "obvious difference between today's prostitution and the practice in old China," namely, that modern prostitution is usually "voluntary."168 The generalization seems questionable. Most Qing women were hardly in a position to enter into prostitution "voluntarily": virtually all of their actions required the approval of either their fathers, husbands or adult sons, ${ }^{169}$ who could either sell or rent them, or put them up for fictitious adoptions-hence the usually coercive nature of Qing prostitution. Yet contemporary lamentations over Qing women's plight, while apparently inspired by genuine sympathy for their exploitation, tend to overdraw a negative contrast with prostitution today: Since PRC women are legally, even if not socially, free agents, prostitutes are viewed as having actively chosen their profession, usually for mercenary and/or vindictive motives. ${ }^{170}$

Prostitutes tend to be young, which makes the ostensible "voluntariness" of their conduct questionable. Studies suggest that $70 \%$ of prostitutes are under 25 years old, with the majority less than 20 years old, ${ }^{171}$ at one reeducation-through-labor institution, $68 \%$ of the prostitutes were between 16 and 20 years old, the youngest being only $14 .{ }^{172}$ While prostitutes themselves

167. Quanguo Renmin Daibiao Dahui Changwu Weiyuanhui Guanyu Yanjin Maiyin Piaochang de Jueding [Decision of the Standing Committee of the National People's Congress on Strictly Forbidding Prostitution and Whoring] [hereinafter Prostitution Provisions], in 1991 ZHONGHUA RENMIN GoNGHEGuO GuOWUYUAN GONGBAo [GAZETTE OF THE STATE COUNCIL, OF THE PEOPLE'S REPUBLIC OF CHINA] 1121, translated in FoREIGN BROADCAST INFORMATION SERVICE-DAILY REPORT: CHINA, Sept. 5, 1991, at 28, 29. The Prostitution Provisions' penalties for prostitutes include forced labor combined with an emphasis on mandatory legal and moral education. Prostitution Provisions, supra, art. 4. According to the authorities, in 1991, China had 103 reeducation reformatories holding a total of 560,000 prostitutes, with a putative success rate of over $80 \%$. Yang Xiaobing, supra note 166, at 29.

168. Zhang Yiquan, The Social Background of Prostitution, SHEHUI [SOCIETY], Oct. 20, 1990, at 38-40, translated in JOINT PUBLICATIONS RESEARCH SERVICE-REPORT: CHINA, Jan. 31, 1991, at 62.

169. Traditionally, women were subject to "three dependencies" (san-cong), which referred to their subordination to different men at different stages in their lives: first a woman was under the authority of her father until she married, then under the authority of her husband until he died, and finally under the authority of her adult sons until her own death. VAN GULIK, supra note 72 , at 28.

170. A study of sex offender profiles claimed that $45 \%$ of women in prostitution were motivated by greed and another $19 \%$ by a "vindictive" desire to get back at husbands or boyfriends who had spurned them. Chinese Sex Survey, supra note 148, at 34 . The press is usually content to note that prostitution is the "easiest road to success for women who have low cultural standards, are materially deprived, have weak morals, and yet who are envious and vain." Ma Li, Don't Let a Historically Ugly Phenomenon Be Revived: An Interview with Wang Xingjuan, Scholar on Women's Issues, MINZHU YU FAZHI [DEMOCRACY AND THE Legal SySTEM], Jan. 1991, at 32, translated in JoINT PUbliCATIONS RESEARCH SERVICE-REPORT: CHINA, May 15, 1991, at 84-85. The article also suggests that a number of women engage in prostitution for the sake of sexual pleasure and claims that over $60 \%$ of the prostitutes at a Guangzhou reeducation-through-labor camp had chosen prostitution either for profit or pleasure.

171. Chen Yehong, supra note 143 , at 67.

172. $\mathrm{Ma} \mathrm{Li}$, supra note 170 , at 85 . The preference for younger women undoubtedly derives in part from the traditional virginity cult, and may have increased in part because of a slowly growing awareness of AIDS and other sexually transmitted diseases. See, e.g., Huang Chin, VD and AIDS: China's New Problem, MING PAO YUE KAN [MING PAo MONTHLY], Feb. 1991, at 33, translated in JoINT PubliCaTions RESEARCH SERVICE-REPORT: CHINA, May 15, 1991, at 87. Huang attributes the recent increase in sexually transmitted diseases largely to the reemergence of large-scale prostitution and the opening up to the West. Id. The Prostitution Provisions address the problem by providing that "[w]hoever is found guilty of 
are viewed as vain, greedy, and vindictive, their male patrons are credited with more benign motives; one study suggested that $40 \%$ of the customers were motivated by "curiosity," and another $46 \%$ simply wanted to have "fun."173

As far as male prostitution is concerned, the laws are silent. In providing penalties for organizing, assisting, or forcing "others" into prostitution, the Prostitution Provisions use the gender-neutral word taren, ${ }^{174}$ yet elsewhere they speak only of "[f]orcing a minor girl of less than 14 years of age" into prostitution, ${ }^{175}$ which suggests that the drafters of the Provisions simply did not contemplate the possibility of minor boys, or men, engaging in prostitution. ${ }^{176}$ This conclusion is also supported by commentators, one of whom states flatly: "The actors in the crime of prostitution are unique. They are limited to women." 177 There is little evidence as to what extent men do in fact trade sex for money, with women or men.

As far as prostitution in general is concerned, then, PRC laws are much more willing than the Qing code to impose the moral maximum on the law and thus to limit even the privileged province of male sexuality. Prostitution laws have often been enforced half-heartedly, through sporadic crackdowns, ${ }^{178}$ but on their face they profess to be gender-neutral and penalize both male patrons and female prostitutes.

\section{Homosexual Relations}

The PRC authorities have usually denied that homosexuality exists in China, and most Chinese agree. ${ }^{179}$ Hence there are no laws or regulations

prostitution or whoring shall undergo mandatory medical examinations for venereal diseases with compulsory treatment of confirmed cases." Prostitution Provisions, supra note 167, art. 4. The number of reported cases of sexually transmitted diseases seems to have decreased after the enactment of the law. Yang Xiaobing, supra note 166, at 29.

173. Chinese Sex Survey, supra note 148, at 34. Although the press has seen the willingness of women to engage in prostitution as the main cause on the supply-side, it has also recognized the existence of a swelling market on the demand-side: the nouveau riche and other beneficiaries of economic reform "do not save their money and put it in expanded reproduction" but, instead, "squander their money and live morally degenerate lives, their most popular pursuits being philandering and gambling." Zhang Yiquan, supra note 168 , at 63.

174. Prostitution Provisions, supra note 167, arts. 1, 2.

175. Id. art. 2.

176. In contrast, in the case of the generally nonsexual crime of abducting minors, the Criminal Law includes both sexes by expressly providing penalties for the abduction of "a boy or girl under the age of fourteen" (bu man shisi sui de nan, nii), and in the case of the generally nonsexual crime of abducting adults, the Criminal Law similarly includes both genders by prohibiting generally the abduction of "people" (renkou). Criminal Law, supra note 33, arts. 184, 141.

177. Chen Yehong, supra note 143, at 69 . The same commentator does note that, as to the crime of luring and keeping women for prostitution, "the actors may be men or women." Id.

178. A typical 1991 crackdown, though resulting in the arrest of some 49,000 persons, lasted only three months. Prostitution Crackdown Will Improve Investment, JOINT PUBLICATIONS RESEARCH SERVICE-REPORT: CHINA, Oct. 28, 1991, at 33.

179. See, e.g., Lin Keh-Ming et al., Overview of Mental Disorders in Chinese Cultures: Review of Epidemiological and Clinical Studies, in NORMAL AND ABNORMAL BEHAVIOR IN CHINESE CULTURE, supra note 97, at 237, 251 (observing that "[t]he majority of Chinese are apparently unaware and unconcerned 
governing homosexuality. Moreover, there is little "gay-bashing," 180 nor are there common Chinese insults related to sexual orientation. This utter invisibility affords some freedom and protection, but prejudice exists; most people find homosexuality improper and distasteful. ${ }^{181} \mathrm{~A}$ well-known Chinese attorney has asserted, "[Homosexuality] affects social order, invades personal privacy and rights and leads to criminal behavior." ${ }^{182}$ The director of the Institute of Marriage and Family puts it less vehemently but equally confidently: "It is not a sin, but it is abnormal and a mental disease, and it can be cured." 183

Professing agnosticism regarding homosexuality, the Marriage Law of 1980 is gender-neutral and does not specifically require that the spouses be of opposite sexes. In practice, however, same-sex marriages are not allowed. ${ }^{184}$ Since registration is required for marriages, ${ }^{185}$ the authorities can simply refuse to register undesirable unions; ${ }^{186}$ the Fujian and Guangdong same-sex marriages in the Qing, in contrast, were possible largely because of the customary, rather than legal, nature of marriage, which put it beyond the

about the existence of homosexuals in their population"); Arthur Kleinman \& David Mechanic, Mental Illness and Psychosocial Aspects of Medical Problems in China, in NORMAL AND ABNORMAL BEHAVIOR IN CHINESE CULTURE, supra note 97, at 331, 348-49 (reporting that doctors in Beijing and Hunan claim to see no cases of homosexuality). On homosexuality in the PRC in general, see the melancholy account-and one of the few treatments of the topic-by Ruan Fang-fu \& Tsai Yung-mei, Male Homosexuality in Contemporary Mainland China, 17 ARCHIVES SEXUAL BeHAV. 189 (1988).

180. Lena H. Sun, Gay Millions: China's Silent Minority, WASH. PoST, Nov. 4, 1992, at A44.

181. Traditional connotations of filial impiety survive as well. In the Republic of China, on the other side of the Taiwan Strait, the groundbreaking novel on the life of disowned gay youth in Taipei by Bai Xianyong, the precursor of Taiwan's modernist literary movement, is entitled Niezi-a Mandarin Chinese reference to extremely unfilial sons. BAI XIANYONG, NIEZI (1989). For an English translation, see PAI HSIEN-YUNG [BAI XIANYONG], CRYSTAL BOYS (Howard Goldblatt trans., 1990).

182. Ruan Fang-fu \& Tsai Yung-mei, supra note 179, at 198.

183. Nicholas D. Kristof, China Using Electrodes To "Cure" Homosexuals, N.Y. TIMES, Jan. 29, 1990, at A2. Among the "cures" that have been tried are the administration of emetics and electric shocks to discourage homoerotic thoughts. Id.

184. See Michael Palmer, The People's Republic of China: More Rules but Less Law, 29 J. FAM. L. 325,329 n.18 (1990-91).

185. Marriage Law of 1980 , supra note 54, art. 7; see also Hunyin Dengji Banfa [Procedures for Marriage Registration], 1986 Fagui Huibian 215. For a detailed analysis of the marriage registration process, see Michael Palmer, The People's Republic of China: New Marriage Regulations, 26 J. FaM. L. 39 (1987-88).

186. Although registration is required to make marriage valid in the eyes of the law, many couples especially in the countryside have been unaware of or have ignored the requirement. Until recently, the failure to register usually carried no sanctions, but attempts have been made to make registration more compulsory. For example, some unregistered couples' children have been denied benefits. Palmer, supra note 184 , at $328-29$. 
regulatory power of the state. ${ }^{187}$ Compulsory heterosexuality is hence not only the social but also the legal norm in the PRC.

Moreover, explicit legal sanctions need not be exercised where other regulations serve to promote the heterosexual model that behooves Chinese socialist morality. For example, it is more difficult for unmarried citizens to obtain housing, join the Party, or get promoted. ${ }^{188}$ Liu Dalin, a Shanghai sexologist, conducted a survey of 254 homosexuals in six major cities and found that over sixty percent of them had in fact married. ${ }^{189}$

Moreover, that the laws are silent on homosexuality does not necessarily mean that homosexuals are left alone. ${ }^{190}$ Men engaging in same-sex relations have in fact been arrested, lawfully or not; catch-all provisions and the use of analogy have allowed law enforcers to intervene where they have perceived moral exigencies. Most charges seem to have been brought, again, under "hooliganism," and some have resulted in prison terms as long as seven or eight years. ${ }^{191}$

Female homosexuality is as taboo a phenomenon as male homosexuality, and it is indeed even more difficult to find reports of lesbianism in the PRC. ${ }^{192}$ Although the marriage resistance movement in Southern Guangdong came to an end with the Japanese invasion in 1935, many of the sisterhoods survived until the founding of the PRC. However, after the establishment of

187. Cf. supra notes $124-26,131-34$, and accompanying text. Nonetheless, the tradition seems to persist at least in some areas of rural Fujian where two men recently went ahead without official registration and arranged a public wedding ceremony with over a hundred guests. In keeping with tradition, the marriage was based on the heterosexual analogue, but this was apparently not enough to legitimate it in the eyes of the law enforcers who denounced it as inconsistent with official morality. No criminal charges were brought against the men, but the "bride" lost his position as a family planning cadre, although a same-sex marriage would seem to have been eminently consistent with his duties of promoting population control. Yiului Tongxinglianzhe Gongran Juxing Hunli [A Pair of Homosexuals Brazenly Carry Out a Wedding Ceremony], FAzHI Ribao [Legal SySTeM DaILY NEwS], Mar. 4, 1989, at 2, cited in Michael Palmer, China, People's Republic of: Reacting to Rapid Social Change, 28 J. FAM. L. 438, 459 (1989-90).

188. Sun, supra note 180, at A44.

189. Id.

190. The Minister of Public Health recently announced that homosexuality, as well as casual sex, is against the PRC law, although the Minister of Justice claimed the contrary. See supra note 142 and accompanying text.

191. Sun, supra note 180, at A44; see also Kristof, supra note 183; Mark S. Del Vecchio, Chinese Police Cast Wide Net for Hooligans, UPI, July 17, 1988, available in LEXIS, News Library, UPI File. There have also been reports of serious harassment. A gay Chinese male interviewed on the National Public Radio complained of beatings by the police: “They don't want to arrest you. It's just that they've got nothing to do and they don't regard you as a human being. If they want to beat you up, they beat you up. And when it's over, you don't dare lodge any complaint." Morning Edition: China Shows More Tolerance Toward Gays (NPR radio broadcast, Feb. 8, 1993), available in LEXIS, News Library, NPR File. Male rapes are even less likely to be reported than less serious cases of harassment. Moreover, unlike the Qing code, PRC legislation is completely silent on the issue, just as it addresses neither homosexuality in general nor male prostitution in particular. The Criminal Law refers only to the crime of raping a woman (funiu), and the provision for statutory rape speaks only of the seduction of a girl (younii) under the age of fourteen. Criminal Law, supra note 33, art. 139. These provisions could of course be applied to male rape by analogy. See supra note 51 .

192. For examples of scattered, sensationalist reporting, see, e.g., Chinese Lesbian Axes Lover to Death, Reuters, Apr. 12, 1991, available in LEXIS, News Library, Txtnws File; and Lesbian Love Worries Warders in China Prisons, Reuters, Sept. 7, 1993, available in LEXIS, News Library, Txtnws File. 
the Communist regime, cadres were widely rumored to have forced surviving elderly lesbians of the movement to marry bachelors and widowers. ${ }^{193}$

In a graphic and highly visible indication of general intolerance of female homosexuality, local officials of the Central Chinese province of Anhui attempted to put a lesbian couple on trial two years ago. ${ }^{194}$ Some symptoms of glacial change in attitudes have nonetheless appeared, including scattered attempts in the media to represent homosexuals as normal people ${ }^{195}$ and the discontinuation of electric shock therapy to "treat" homosexuality. ${ }^{196}$ However, even foreign governments have recognized the severity of discrimination against homosexuals in China today; in 1992, a gay Chinese couple became the first to be granted asylum in Australia on the basis of sexual orientation. ${ }^{197}$

In sum, insofar as the PRC officially refrains from regulating homosexual relations at all, its legislation is both tolerant and gender-neutral. Yet the open-ended and procedurally flexible Security Administration Punishment Act and catch-all provisions in other laws have been, and are, used to harass homosexuals. Thus, in reality, the PRC seems to be even more puritanical than the Qing which denounced homosexual relations in principle but allowed them in practice, at least for men. Yet, while homosexuality appears to be equally taboo for both men and women in the PRC, this need not indicate equal respect, or disrespect, for the sexes. More plausibly, it suggests a fear of homosexuality as a transgression of the persisting traditional sexual orthodoxy;

193. Sankar, supra note 130 , at 70 . Most surviving sisterhoods of the marriage resistance movement fled to South East Asia after 1935; some were still in existence in Hong Kong at least in the early 1980's. Apparently a handful survive even in the PRC. Id. at 69-70.

194. Uli Schmetzer, Puritan China Faces Homosexuality, CHI. TRIB., Sept. 27, 1992, at C6. The Ministry of State Security in Beijing eventually instructed the Anhui officials to leave the women alone on the grounds that there were no laws covering their alleged offenses. Id.

195. For example, homosexuality is one of the main themes in Farewell My Concubine, a film by director Chen Kaige that shared the top prize at the Cannes film festival in May 1993. The film was to open in Beijing in July, but only the premiere was allowed to take place and all other showings were cancelled. Premiere and Dernière, ECONOMIST (U.S. ed.), July 31, 1993, at 34. Although showings were eventually resumed, Jargely due to an international outcry, scenes dealing with homosexuality as well as several scenes depicting the Cultural Revolution were cut. Patrick E. Tyler, China's Censors Issue a Warning, N.Y. TMME, Sept. 4, 1993, at A11.

Part of the ever-so incremental recent increase in gay visibility in the PRC is probably due to a growing awareness of AIDS. See supra note 172. The first Chinese person infected with HIV, reported in October 1989, was described as a male salesperson "addicted to homosexuality" who had contracted the virus from a foreign sexual partner. Huang Chin, supra note 172 , at 89 . Although most of the transmission of HIV in China today is attributable to needle-sharing by drug-users-rather than gay "sex-addicts"-the association of AIDS with homosexuality remains nevertheless strong in the popular consciousness, much as it does in the West.

China's first AIDS Hotline, established in 1991, is in fact flooded with calls. Sun, supra note 180. Yet most efforts to reach the gay population have generally met with official indifference or outright hostility. When Wan Yanhai, founder of the AIDS Hotline, started advocating publicly the formation of nongovernmental self-help groups by gays, prostitutes, and intravenous drug-users to combat the spread of AIDS, he was fired from his post at the National Health Education Institute. Geoffrey Crothall, Fall from Grace of the Mainland's "Mr. AIDS," S. CHINA MORNING POST, July 18, 1993, at 8.

196. Sun, supra note 180 , at A44.

197. Gay Couple Escapes Mainland Repression, S. ChINA MORNING POsT, Oct. 25, 1992, at 7. 
as dissidence from gender, it is liable to subvert sex roles and thereby call the millennial male-female hierarchy into question. Gay men and lesbian women are likely oppressed "equally" not in order to promote gender-neutral justice, but rather to prevent them from upsetting the gendered injustice of static sex roles. Nevertheless, the official statutory morality-whatever it may be worth-discriminates neither on the basis of sexual orientation nor of sex.

\section{Sex Offenses in Qing and PRC Compared}

The above comparative survey demonstrates that Qing laws regulating marital transgressions, prostitution, and homosexual relations were governed by the principle of gender inequality, while the corresponding PRC laws are premised on a principle of gender equality. Yet the two regimes share a similar foundational understanding: Both prefer rule by an internalized sexual morality to law, and both tend to treat the latter as an aspirational ideal rather than a binding directive. A generally known but often unarticulated sexual morality provides the standard by which violations are recognized, while law metes out the penalties.

Yet the two regimes' records on enforcement are not identical. The above survey suggests that nonenforcement of the Qing sexual morality based on gender inequality was the exception rather than the rule: the law required that men be treated preferentially, and only occasionally was its spirit not respected. In the PRC, however, resistance to the new sexual morality of gender equality seems to have been relatively consistent: now that the law calls for an end to male sexual privilege, it is much more likely to be compromised. In short, a statutory morality of gender inequality coincided with a reality of gender inequality in the Qing, while the official PRC morality of gender equality has failed to translate into a corresponding reality. ${ }^{198}$

The view of Chinese law as a secondary enforcement mechanism of an internalized morality offers one explanation for the difference. That Qing laws were enforced relatively faithfully suggests that the internalized morality of the law enforcers (magistrates, clan heads, husbands, fathers) coincided with the patriarchal sexual morality embodied in the law itself. The revolutionary sexual ethic of gender equality in PRC law, in contrast, represents a radical break with millennia of patriarchy and an attempt by an ideological elite to legislate a new socialist morality. Hence, PRC laws do not so much reflect as seek to transform the internalized sexual morality of both the law enforcers and the masses. To the extent that law is still conceptualized as ultimately relying on the moral intuitions of its enforcers, any effort to legislate a new morality is

198. On the social inequality of the sexes in the PRC, see generally PHYLLIS ANDORS, THE UNFINISHEd LibERATION OF CHINESE WOMEN 1949-1980 (1983), ElisABETH CROLL, FEMINISM AND SOCIALISM IN CHINA (1978), JUdTH STACEY, PATRIARCHY AND SOCIALIST REVOLUTION IN CHINA (1983), and WOLF, supra note 58. 
but a quest for a cart that would pull the horse. The new laws are not likely to be enforced fully until the old Confucian morality is exorcised, rather than vice versa, or, alternatively, until law is viewed as more than a vehicle for conveying official moral aspirations. ${ }^{199}$

Ironically, it is the traditional conflation of law and morality that ultimately makes PRC laws governing sexual morality susceptible to abuse and gives law enforcers the means to eviscerate them; the open-endedness and flexibility of the law, flowing from its largely moral nature, provides law enforcers with the technical capacity-catch-all provisions and the analogy-to use the law for their own ethical, or unethical, ends, even when those ends are opposed to the underlying morality of the law. Moreover, writing aspirational goals into laws makes it necessary to compromise those laws in practice, which in turn provides a semblance of legitimacy to selective enforcement.

\section{CONCLUSION}

Despite calls for the creation of a socialist ethical system in the PRC ${ }^{200}$ and demands that equality of sexes be embodied in sexual morality ${ }^{201}$ inequality between the sexes persists; traditional notions of gender hierarchy inform the interpretation and administration of laws, often to the point of nullifying their egalitarian spirit. One forthright Chinese tour guide told a group of American female lawyers visiting in China, "[Confucian morality] still works in the minds of people."202 In Margery Wolf's words, "contemporary China proves beyond a doubt that socialism and patriarchy can exist in stable harmony."203

The preference for rule by internalized morality rather than law hurts the very legitimacy of law in the long run insofar as it tends to make legislation a secondary form of social control and render it aspirational rather than binding by nature. Inevitably, aspirational laws are compromised, making the administration of justice unpredictable and arbitrary-or worse still, allowing

199. Of course, one might legitimately question even the good faith of the revolutionary elite's call for a new morality of gender equality. Exploration of the question is beyond the scope of this Note, but even if PRC legislation was intended as mere window-dressing from the beginning, it only lends further support to the notion that the PRC is still ruled by the moral intuitions of men rather than laws.

200. See, e.g., Wang Renzhi, Let Socialist Ideas and Ethics Become Common Practice, Speech at the National Work Conference on Activities of Building Spiritual Civilization, translated in JoINT PUBLICATIONS RESEARCH SERVICE-REPORT: CHINA, Feb. 6, 1991, at 1 (calling for inculcation of socialist ethics through education and mass participation); $\mathrm{Xu}$ Weicheng, Create a Socialist Ethical System with Chinese Characteristics, Speech at the Fifth National Ethics Conference of the PRC, translated in JOINT PUBLICATIONS RESEARCH SERVICE-REPORT: CHINA, Jan. 31, 1991, at 57.

201. See, e.g., Wang Youqin, Guanyu Xing Daode de Yixie Sikao [Some Reflections Concerning Sexual Morality], ZHONGGUO FunÜ [CHINESE WOMEN], Oct. 1985, at 10-12, cited in HONIG \& HERSHATTER, supra note 144, at 121.

202. Adele I. Springer, Status of Women in the People's Republic of China, 66 WOMEN LAw. J., Spring 1980, at 17.

203. WOLF, supra note 58, at 261. 
it to become systematically discriminatory. In short, as long as laws calling for gender equality are viewed as laudable but not necessarily enforceable moral principles, the sexual revolution is likely to remain on hold in China. 
